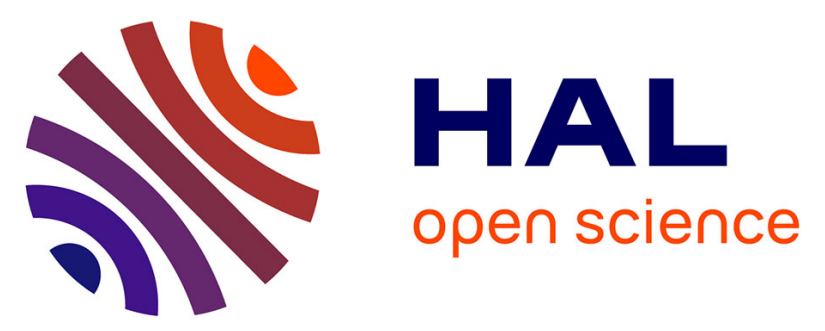

\title{
Pan-Arctic optical characteristics of colored dissolved organic matter: Tracing dissolved organic carbon in changing Arctic waters using satellite ocean color data
}

Atsushi Matsuoka, Emmanuel Boss, Marcel Babin, Lee Karp-Boss, Mark Hafez, Alex Chekalyuk, Christopher W Proctor, P. Jeremy Werdell, Annick

Bricaud

\section{To cite this version:}

Atsushi Matsuoka, Emmanuel Boss, Marcel Babin, Lee Karp-Boss, Mark Hafez, et al.. Pan-Arctic optical characteristics of colored dissolved organic matter: Tracing dissolved organic carbon in changing Arctic waters using satellite ocean color data. Remote Sensing of Environment, 2017, 200, pp.89-101. 10.1016/j.rse.2017.08.009 . hal-01685512

\section{HAL Id: hal-01685512 \\ https://hal.sorbonne-universite.fr/hal-01685512}

Submitted on 16 Jan 2018

HAL is a multi-disciplinary open access archive for the deposit and dissemination of scientific research documents, whether they are published or not. The documents may come from teaching and research institutions in France or abroad, or from public or private research centers.
L'archive ouverte pluridisciplinaire HAL, est destinée au dépôt et à la diffusion de documents scientifiques de niveau recherche, publiés ou non, émanant des établissements d'enseignement et de recherche français ou étrangers, des laboratoires publics ou privés. 


\title{
Pan-Arctic optical characteristics of colored dissolved organic matter: Tracing dissolved organic carbon in changing Arctic waters using satellite ocean color data
}

\author{
Atsushi Matsuoka $^{\mathrm{a}, \mathrm{b}, *}$, Emmanuel Boss ${ }^{\mathrm{c}}$, Marcel Babin ${ }^{\mathrm{a}, \mathrm{b}}$, Lee Karp-Boss ${ }^{\mathrm{c}}$, Mark Hafez ${ }^{\mathrm{d}}$, \\ Alex Chekalyuk $^{\mathrm{d}}$, Christopher W. Proctor ${ }^{\mathrm{e}, \mathrm{h}}$, P. Jeremy Werdell ${ }^{\mathrm{e}}$, Annick Bricaud ${ }^{\mathrm{f}, \mathrm{g}}$ \\ a Takuvik Joint International Laboratory, Département de Biologie, Université Laval, 1045, avenue de la Médecine, Québec, QC G1V 0A6, Canada \\ b Takuvik Joint International Laboratory, CNRS, 1045, avenue de la Médecine, Québec, QC G1V 0A6, Canada \\ c School of Marine Sciences, University of Maine, 458 Aubert Hall Orono, ME 04469, USA \\ d Lamont-Doherty Earth Observatory, Columbia University, 61 Route 9W, - PO Box 1000, Palisades, NY 10964-8000, USA \\ e NASA Goddard Space Flight Center, Mail Code: 616.2, Greenbelt, MD 20771, USA \\ ${ }^{\mathrm{f}}$ Sorbonne Universités, UPMC Univ Paris 06, UMR 7093, LOV, Observatoire océanologique, F-06230 Villefranche/mer, France \\ g CNRS, UMR 7093, LOV, Observatoire océanologique, F-06230 Villefranche/mer, France \\ h Science Systems and Applications, Inc., 10210 Greenbelt Road, Suite 600, Lanham, MD 20706, USA
}

\begin{abstract}
A B S T R A C T
Light absorption of the colored fraction of dissolved organic matter (CDOM) is a dominant optical component of the Arctic Ocean (AO). Here we show Pan-Arctic characteristics of CDOM light absorption for various Arctic regions covering both coastal and oceanic waters during the Tara Oceans Polar Circle expedition. The Siberian (or eastern) side of the AO is characterized by higher CDOM absorption values compared to the North American (or western) side. This is due to the difference in watersheds between the eastern and western sides of the AO and is consistent with an Arctic absorption database recently built by Matsuoka et al. (2014). A direct comparison between in situ and satellite data demonstrates that CDOM absorption is derived Arctic-wide from satellite ocean color data with an average uncertainty of $12 \%$ (root mean square error of $0.3 \mathrm{~m}^{-1}$ ) using our previously published algorithm. For river-influenced coastal waters, we found a single and highly significant relationship between concentrations of dissolved organic carbon (DOC) and CDOM absorption $\left(r^{2}>0.94\right)$ covering major Arctic river mouths. By applying this in situ relationship to satellite-derived CDOM absorption, DOC concentrations in the surface waters are estimated for river-influenced coastal waters with an average uncertainty of $28 \%$. Implications for the monitoring of DOC concentrations in Arctic coastal waters are discussed.
\end{abstract}

\section{Introduction}

Colored dissolved organic matter (CDOM) refers to the fraction of the dissolved organic matter pool that absorbs light in water, and is quantified by its spectral absorption coefficient $\left[\mathrm{m}^{-1}\right]$. CDOM plays a variety of roles in ocean physical and biogeochemical processes (e.g., Moran and Zepp, 1997; Miller et al., 2002; Matsuoka et al., 2012, 2015) and provides the possibility to trace, using a simple optical measurement, the concentration of dissolved organic carbon (DOC) in seawater, the second largest reservoir of carbon in the ocean (Hansell, 2002). Strong correlations between DOC concentration and CDOM absorption have been reported for river-influenced coastal waters at all latitudes (e.g., Massicotte et al., in press and references therein), highlighting the potential usefulness of CDOM to study DOC distributions in these waters.

Despite the important role of CDOM in biogeochemical cycles and as a DOC proxy, our ability to document it in situ has been restricted by sea ice in the Arctic Ocean. Since the early 2000s, however, partly due to a significant reduction of summer extent of the Arctic ice pack, a number of in situ datasets have been acquired, and recently an Arctic seawater light absorption database was built to provide a synoptic view of the spatial and temporal variations of CDOM in the Arctic Ocean (Matsuoka

\footnotetext{
* Corresponding author at: Takuvik Joint International Laboratory, Département de Biologie, Université Laval, 1045, avenue de la Médecine, Québec, QC G1V 0A6, Canada.

E-mail addresses: Atsushi.Matsuoka@takuvik.ulaval.ca (A. Matsuoka), emmanuel.boss@maine.edu (E. Boss), Marcel.Babin@takuvik.ulaval.ca (M. Babin), lee.karp-boss@maine.edu (L. Karp-Boss), chekaluk@ldeo.columbia.edu (A. Chekalyuk), christopher.w.proctor@nasa.gov (C.W. Proctor), jeremy.werdell@nasa.gov (P.J. Werdell), annick.bricaud@obs-vlfr.fr (A. Bricaud).
} 
et al., 2014). Still, a large part of the Siberian (or eastern) side of the Arctic Ocean (EAO), where high concentrations of organic carbon are delivered by river discharge (Raymond et al., 2007), was undersampled in the above-mentioned study, which impeded comparing optical properties between the EAO and the North American (or western) side of the Arctic Ocean (WAO). This is an important gap because a very large amount of organic carbon ( $400 \mathrm{Pg}$; $\mathrm{Pg}=10^{15} \mathrm{~g}$ ) is stored in the upper three meters of the northern Siberia soils (McGuire et al., 2009) and a significant fraction of this organic carbon may be delivered by river discharge into the Arctic Ocean, which might alter biogeochemical processes of the ocean (e.g., McGuire et al., 2009; IPCC, 2013). We lack knowledge about how the DOC budget of the Arctic Ocean will be modified as a consequence of ongoing global warming. Remote sensing of CDOM provides a powerful mean for tracing DOC in the Arctic Ocean and observing its dynamics and response to climate change from space.

The objectives of this study are therefore 1) to examine optical characteristics of CDOM in the different Arctic seas, 2) establish a relationship between DOC concentration and CDOM absorption coefficient that can be applied to wide range of river-influenced coastal waters, and 3) apply this relationship to satellite-derived CDOM absorption for estimating DOC concentrations from space. With known uncertainties, examples of monitoring of spatial-temporal variability in DOC concentrations for Arctic river-influenced coastal waters are shown at the end of the present study.

\section{Materials and methods}

The Tara Oceans Polar Circle expedition was conducted from 24 May to 5 November 2013 following a long transect in the Arctic Ocean (Fig. 1a). While the data presented in this study were mainly obtained from the Tara expedition, an Arctic absorption database built by Matsuoka et al. (2014) (hereafter referred to as the M2014 database), is also used here for comparison. Briefly, the M2014 database includes data from Western and Eastern Arctic Ocean covering Beaufort, Chukchi, Kara, and Laptev seas from May to October (Table 1).

To establish a DOC versus $\mathrm{a}_{\mathrm{CDOM}}(443)$ relationship that is applicable to wide range of river-influenced coastal waters of the Arctic Ocean, we compiled and used publicly available data in addition to the Tara data (Section 2.1.4; Table 1). This provides a confidence of the general relationship in terms of statistics. Similarly, data obtained from MALINA, ICESCAPE2010, ICESCAPE2011 cruises included in the M2014 database (Matsuoka et al., 2014), in addition to Tara data, were also used to evaluate the performance of the CDOM algorithm developed by Matsuoka et al. (2013) (hereafter referred to as gsmA algorithm; see Sections 2.1 .5 and 2.2.1).

In the present study, we refer waters having $\mathrm{a}_{\mathrm{CDOM}}(443)<0.1 \mathrm{~m}^{-1}$ and $>0.1 \mathrm{~m}^{-1}$ as oceanic and coastal waters, respectively. Of coastal waters, these waters are specifically referred to as river-influenced coastal waters when the $\mathrm{a}_{\mathrm{CDOM}}(443)$ shows a significantly high correlation with salinity or DOC.

\subsection{In situ data}

\subsubsection{CDOM absorption}

2.1.1.1. UltraPath measurements. Light absorption coefficients of CDOM using an UltraPath (World Precision Instruments, Inc.) was determined by following the protocols proposed by Bricaud et al. (2010) and Matsuoka et al. (2012). To avoid repeating the protocols, only relevant points to the present study are recalled here. A sample was collected daily from a surface CTD/Niskin bottle or the in-line system flow-through (when no CTD deployment took place) into glass bottles pre-rinsed with MilliQ water. The sample bottles were covered with aluminium foil to avoid a potential effect of light degradation on $\mathrm{CDOM}$ in the water. These samples were filtered within a few hours after the sampling using $0.2 \mu \mathrm{m}$ GHP filters (Acrodisc Inc.) pre-rinsed with $200 \mathrm{ml}$ of Milli-Q water. Absorbance spectra of filtrates were measured from 200 to $727 \mathrm{~nm}$ with $1 \mathrm{~nm}$ increments relative to a salt solution that was used as a reference. The reference was prepared to have a similar salinity as samples ( \pm 2 salinity units) using Milli-Q water and granular $\mathrm{NaCl}$ precombusted in an oven (at $450{ }^{\circ} \mathrm{C}$ for $4 \mathrm{~h}$ ). Abnormally high absorbance values in the near infrared spectral domain were sometimes observed due to the presence of air bubbles in the cell of the sample. These suspicious spectra were removed prior to analysis. While significant effort was made to minimize the difference in temperature and salinity between a sample and reference water during our cruise, this was challenging especially for areas in which waters showed a large salinity gradient with different water temperature. The temperature difference was minimized by placing both the reference and the filtrates at $4{ }^{\circ} \mathrm{C}$ in the dark for up to $1 \mathrm{~h}$. The salinity difference was minimized by subtracting the mean value of $\mathrm{OD}_{\mathrm{CDOM}}(\lambda)$ between 683 and $687 \mathrm{~nm}\left(\mathrm{OD}_{\text {null,CDOM }}\right)$ from the whole spectrum following Babin et al. (2003) and CDOM absorption coefficients $\left(\mathrm{a}_{\mathrm{CDOM}}(\lambda), \mathrm{m}^{-1}\right)$ were calculated as follows:

$\mathrm{a}_{\mathrm{CDOM}}(\lambda)=2.303 \frac{\left[\mathrm{OD}_{\mathrm{CDOM}}(\lambda)-\mathrm{OD}_{\text {null,CDOM}}\right]}{l}$

where 2.303 is a factor for converting base e to base 10 logarithms, and $l$ is the optical pathlength (m). A $2 \mathrm{~m}$ optical pathlength was used for the measurement, except for water having high CDOM content ( $>2.0 \mathrm{~m}^{-1}$; Matsuoka, unpublished data) where $0.1 \mathrm{~m}$ pathlength was used. Replicates of CDOM absorption spectra were averaged for each measurement.

We acknowledge that scattering due to colloids might have influenced absorption measurement using a long pathlength $(>0.5 \mathrm{~m}$; Floge et al., 2009), which in turn might have influenced CDOM spectra when applying null-correction. However, for Mackenzie river mouth where the highest particle concentrations of the Arctic Ocean are observed (Holmes et al., 2002), Matsuoka et al. (2012) showed that CDOM absorption measurements using an UltraPath with 2-m pathlength were within the instrument resolution from those measured using a PerkinElmer Lambda-19 spectrophotometer with $10-\mathrm{cm}$ cell. These results suggest that the impact of colloidal scattering on our absorption measurement can be considered as negligible in the present study.

2.1.1.2. ac-s measurements. To obtain CDOM measurements between those done with the UltraPath, we used a hyper spectral ac-s instrument installed in an automated flow-through system (red crosses in Fig. 1a). Hereafter CDOM absorption coefficients provided by the ac-s are noted as $\mathrm{a}_{\mathrm{CDOM}}^{\text {acs }}(\lambda)$ (in $\mathrm{m}^{-1}$ ).

Filtered water was pumped through the ac-s (WET Labs) for $10 \mathrm{~min}$ per hour (see Boss et al., 2013 for the ac-s setup). The last minute of every $10 \mathrm{~min}$ filtered cycle was median-binned and saved. No clean water spectra for calibration were collected with the ac-s during the expedition, and instrument was cleaned weekly. Therefore, the spectra potentially contained errors due to instrument drift (it is acknowledged that the ac family of instrument drifts in time as presented by Twardowski et al., 1999; Temperature and salinity effects are insignificant as we focus here only on the $400-550 \mathrm{~nm}$ spectral range; Pegau et al., 1997). To solve this issue, the ac-s data were shifted spectrally to match the corresponding UltraPath measurements in this range. The calibration for ac-s spectra were made by computing and offset between UltraPath and dissolved ac-s measurements done within 25 min:

Offset $=\mathrm{a}_{\mathrm{CDOM}}^{\mathrm{UP}}(\lambda)-\operatorname{median}\left(\mathrm{a}_{\mathrm{CDOM}}^{\text {acs-obs }}(\lambda)\right)$

where $\mathrm{a}_{\mathrm{CDOM}}^{\mathrm{UP}}(\lambda)$ and $\mathrm{a}_{\mathrm{CDOM}}^{\mathrm{acs}-\mathrm{obs}}(\lambda)$ represent CDOM absorption using UltraPath (UP) and ac-s, respectively. There were 59 such matchups within $12 \mathrm{~h}$ and $20 \mathrm{~km}$ from an UP measurement of dissolved matter, the nearest calibration spectra (in time) was used to correct the spectra:

$\mathrm{a}_{\mathrm{CDOM}}^{\text {acs }}(\lambda)=\mathrm{a}_{\mathrm{CDOM}}^{\text {acs-obs }}(\lambda)+$ Offset(nearest)

The ac-s was then interpolated with 1-nm increments.

A spectral slope $\left(\mathrm{S}_{\mathrm{CDOM}}, \mathrm{nm}^{-1}\right)$ was calculated by fitting an 


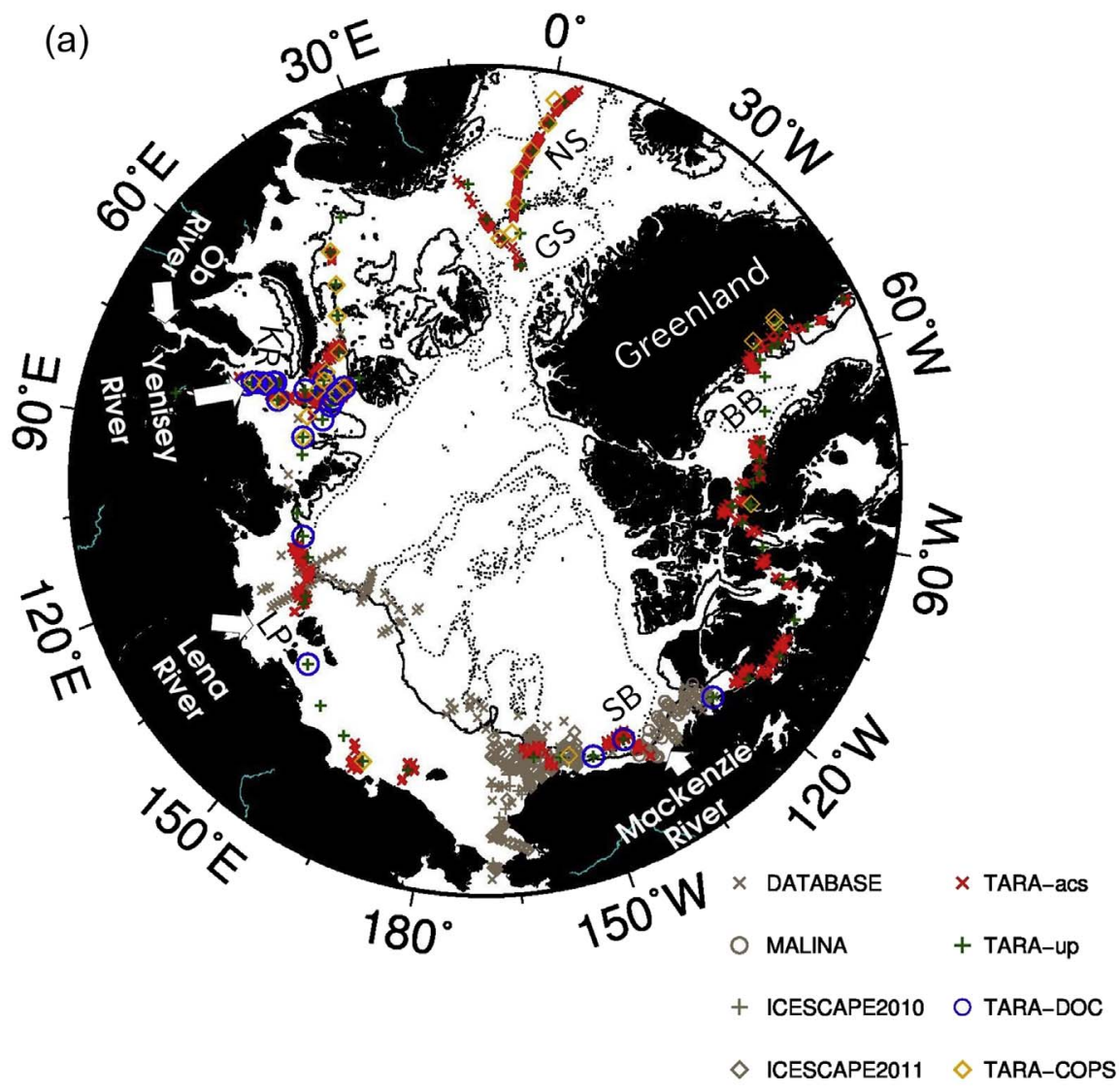

Fig. 1. (a) A map of the Arctic Ocean showing sampling stations during the Tara Oceans Polar Circle cruise for colored dissolved organic matter (CDOM) absorption measurement using a ac-s (red) and an UltraPath (green), DOC concentration determination (blue), and radiometric measurements using a C-OPS (orange). Gray symbols show sampling stations for an Arctic absorption database built by Matsuoka et al. (2014) (M2014). Among the M2014, sampling stations for MALINA (gray circle), ICESCAPE2010 (gray plus), and ICESCAPE2011 (gray diamond) cruises are particularly indicated. GS, NS, KR, LP, SB, and BB represent Greenland Sea, Norwegian Sea, Kara Sea, Laptev Sea, Southern Beaufort Sea, and Baffin Bay, respectively. Contour lines for 200-m and 2000-m are depicted as solid and dashed black lines, respectively. (b) Frequency distribution of ac-s $\mathrm{a}_{\mathrm{CDOM}}(443)\left(\mathrm{m}^{-1}\right)$ obtained for the Tara (pink) and M2014 database (gray). (c) Same as (b) but for $\mathrm{S}_{\mathrm{CDOM}}\left(\mathrm{nm}^{-1}\right)$. (For interpretation of the references to color in this figure legend, the reader is referred to the web version of this article.)

(b

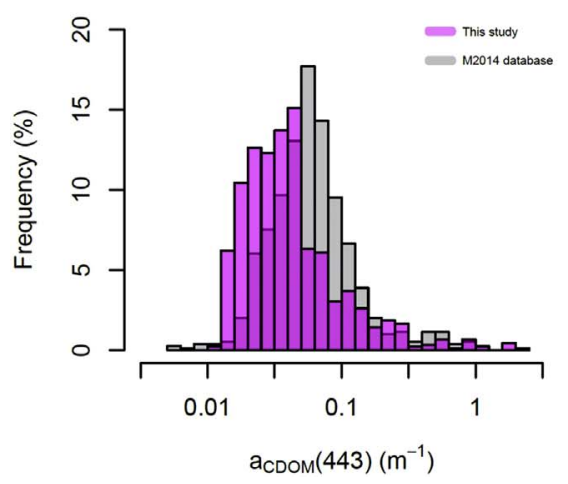

(c)

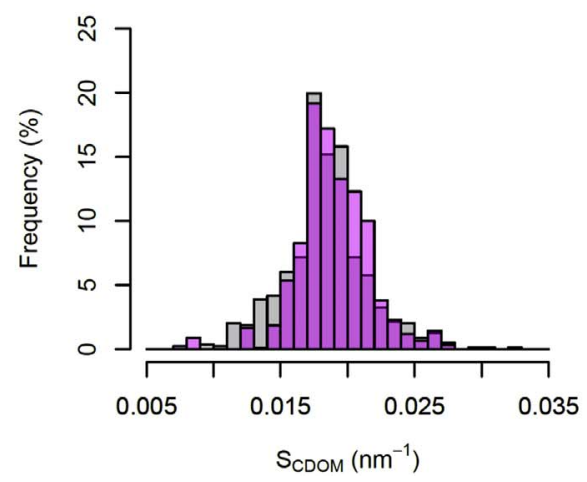

exponential equation to the data in the spectral domain (i.e., 400-406 to $500 \mathrm{~nm}$ ) as follows:

$\mathrm{a}_{\text {CDOM }}(\lambda)=\mathrm{a}_{\text {CDOM }}^{\text {acs }}(443) * \mathrm{e}^{-\mathrm{S}_{\text {CDOM }}(\lambda-443)}$

The spectral range was chosen to be as similar as possible relatively to the one for the M2014 database (350 to $500 \mathrm{~nm}$; Matsuoka et al., 2014) while avoiding the range from 500 to $550 \mathrm{~nm}$ for ac-s measurements where the signal was, on occasion, within the uncertainty of the measurement (not shown). Using the MALINA data, which exhibited a large variability in $\mathrm{a}_{\mathrm{CDOM}}(\lambda)$ (see Matsuoka et al., 2012 for details), it

Table 1

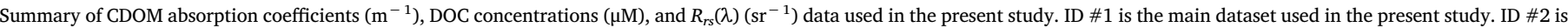

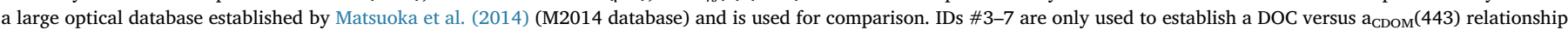

\begin{tabular}{|c|c|c|c|c|c|c|}
\hline ID \# & Dataset & Location & Period & Variable & $N$ & Reference \\
\hline 1 & Tara & Pan-Arctic Ocean & 2013-05-24-2013-11-05 & $\mathrm{CDOM}^{\mathrm{a}}(\mathrm{DOC}) R_{r s}(\lambda)$ & 919 (20) 26 & This study \\
\hline 2 & M2014 database & Beaufort, Chukchi, Kara, and Laptev Seas & 2002-05-05-2011-10-13 & $\mathrm{CDOM} R_{r s}(\lambda)$ & 79777 & Matsuoka et al. (2014) \\
\hline 3 & R2007 & Southern Beaufort Sea & 2002-07-22-2004-06-17 & CDOM (DOC) & $2(2)$ & Retamal et al. (2007) \\
\hline 4 & O2009 & Southern Beaufort Sea & 2002-10-01-2004-08-01 & CDOM (DOC) & $14(14)$ & Osburn et al. (2009) \\
\hline 5 & M2012 & Southern Beaufort Sea & $2009-07-30-2009-08-27$ & CDOM (DOC) & $35(35)$ & Matsuoka et al. (2012) \\
\hline 6 & G2015 & Kara and Laptev Seas & 2013-09-01-2013-09-06 & CDOM (DOC) & $35(35)$ & Gonçalves-Araujo et al. (2015) \\
\hline 7 & O2016 & Southern Beaufort Sea & 2003-06-01-2011-06-01 & CDOM (DOC) & $9(9)$ & Osburn et al. (2016) \\
\hline
\end{tabular}

a 919 of data were obtained from ac-s measurements that were calibrated against UltraPath ones as described in Section 2.1.1. 
Table 2

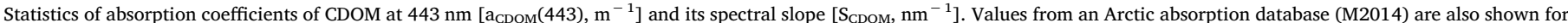
comparison.

\begin{tabular}{|c|c|c|c|c|c|c|}
\hline \multirow{2}{*}{$\begin{array}{l}\text { Parameters } \\
\text { Statistics }\end{array}$} & \multicolumn{3}{|c|}{$\mathrm{a}_{\mathrm{CDOM}}(443)\left(\mathrm{m}^{-1}\right)$} & \multicolumn{3}{|c|}{$\mathrm{S}_{\mathrm{CDOM}}\left(\mathrm{nm}^{-1}\right)$} \\
\hline & Median & $5 \%$ percentile & $95 \%$ percentile & Median & $5 \%$ percentile & $95 \%$ percentile \\
\hline Tara Oceans Polar Circle (the present study) & 0.037 & 0.015 & 0.241 & 0.0187 & 0.0151 & 0.0233 \\
\hline M2014 database (Matsuoka et al., 2014) & 0.058 & 0.021 & 0.249 & 0.0183 & 0.0133 & 0.0240 \\
\hline
\end{tabular}

was demonstrated that the difference in the two spectral slopes using the two different spectral ranges was low (root mean square error, RMSE $=0.0012 \mathrm{~nm}^{-1}, N=381$ ). To confirm that the RMSE does not influence our results, we used a bootstrap method which randomly adds uncertainties (both positive and negative of variable magnitude independent at each wavelength) based on the RMSE (i.e., $0.0012 \mathrm{~nm}^{-1}$ ) as follows. For each $\mathrm{a}_{\mathrm{CDOM}}(\lambda)$ spectrum, a maximum error $\left(\varepsilon_{\max }\right)$ was calculated using $\mathrm{a}_{\mathrm{CDOM}}(443)$ and $\mathrm{S}_{\mathrm{CDOM}} \pm 0.0012$ at $400 \mathrm{~nm}$. The positive and negative $\varepsilon_{\max }$ was then randomly added to $\mathrm{a}_{\mathrm{CDOM}}(\lambda)$ from 400 to $500 \mathrm{~nm}$. A $\mathrm{S}_{\mathrm{CDOM}}$ was calculated to the $\varepsilon_{\max }$-included data as described above. This analysis was repeated a thousand times. The statistics associated with the new $\mathrm{S}_{\mathrm{CDOM}}$ were obtained and compared to those in the Table 2 . Results were not significantly different from the values presented in the Table 2 ( $p=0.10$, $t$-test).

Prior to the analysis, we removed all the spectra not within a 1 day temporal window around an UltraPath measured spectra (in total, 919 ac-s spectra were retained).

\subsubsection{CDOM fluorescence}

An Aquatic Laser Fluorescence Analyzer (ALFA, WETLabs; Chekalyuk et al., 2014; Chekalyuk and Hafez, 2013; Chekalyuk et al., 2016) was installed as part of the Tara flow-through system. The ALFA instrument provides dual-wavelength excitation (405 and $514 \mathrm{~nm}$ ) of laser-stimulated emission (LSE) for spectral and temporal fluorescence analysis. Spectral deconvolution (SDC) was used to examine fluorescence associated with a specific constituent and Raman scattering in water (R). The Raman scattering intensity was used for fluorescence normalization to provide adjustment for potential variability of the excitation source intensity and water optical properties (Chekalyuk and Hafez, 2008). We analyzed the ALFA SDC assessment of the CDOM fluorescence/Raman ratios measured using laser excitation at $405 \mathrm{~nm}$ and $514 \mathrm{~nm}$. The ALFA sensor was cleaned weekly following the manufacturer recommended protocol.

\subsubsection{DOC concentration}

Surface water samples were collected directly from either the Rosette Niskin bottle or from the flow-through system (at the same time as the UP measurements; see Fig. 1a) into acid-clean $60 \mathrm{ml}$ HDPE Nalgene bottles through pre-combusted GF/F filters $\left(450{ }^{\circ} \mathrm{C}\right.$ for $4 \mathrm{~h}$; e.g., Carlson et al., 2010; Shen et al., 2012). Samples were then immediately stored at $-20{ }^{\circ} \mathrm{C}$. At the end of the cruise the samples were shipped to the University of South Carolina for analysis. Concentrations of dissolved organic carbon (DOC) were determined using the hightemperature combustion method and a Shimazu total organic carbon (TOC- $\mathrm{V}_{\mathrm{CSN}}$ ) analyzer (Shen et al., 2016). In total, 20 samples were collected for DOC analyses.

\subsubsection{Additional CDOM absorption and DOC concentrations data}

While the dataset obtained from the Tara cruise provide a large number of CDOM absorption spectra, the number of the corresponding DOC concentrations data is limited (i.e., $N=20$ ). To augment our dataset for our analysis, we added publicly available datasets for both CDOM absorption and DOC concentrations data from Retamal et al. (2007), Osburn et al. (2009), Matsuoka et al. (2012), Goncalves-Araujo et al. (2015), and Osburn et al. (2016) (hereafter referred to as R2007, O2009, M2012, G2015, and O2016, respectively; see Table 1). These data cover major Arctic river mouths including both Siberian and North American sides.

CDOM absorption was determined using a traditional spectrophotometer with a 5 or $10 \mathrm{~cm}$ quartz cell, except for M12 where an UltraPath was used as described above (section UltraPath measurements in Section 2.1.1). DOC concentrations were determined based on high temperature oxidation using a TOC analyzer for the mentioned data.

\subsubsection{Remote sensing reflectance}

We followed the NASA Ocean Optics Protocols (Mueller and Austin, 1995) and Hooker et al., 2013 to measure in-water upwelled radiance $\left(L_{u}, \mu \mathrm{W} \mathrm{cm}^{-2} \mathrm{~nm}^{-1} \mathrm{sr}^{-1}\right.$ ) and downward irradiance ( $E_{d}, \mu \mathrm{W}$ $\mathrm{cm}^{-2} \mathrm{~nm}^{-1}$ ). These data were obtained at 19 wavelengths ranging from 320 to $780 \mathrm{~nm}$ (10 nm full-width at half-maximum, FWHM). A compact-optical profiling system (C-OPS, Biospherical Instruments Inc.) (Morrow et al., 2010) was deployed at 29, 36, and 19 stations for Tara Arctic, MALINA, and ICESCAPE2010 cruises, respectively. For the ICESCAPE2011 cruise, a profiling reflectance radiometer series 800 (PRR-800, Biospherical Instruments Inc.; $10 \mathrm{~nm}$ FWHM) was deployed at 24 stations. The above-water downward irradiance, so-called the global solar irradiance ( $E_{s}$ : sum of direct and diffuse components) were used to correct $E_{d}$ and $L_{u}$ data for change in the incident light field during water column profiling. The effect of ship shadow was minimized by deploying the in-water spectroradiometer away from the main ship body. Only data having tilt angles $<5^{\circ}$ were used for analysis in the present study, as recommended by Hooker et al. (2013). Subsurface $L_{u}$ values at null depth (i.e., $L_{u}\left(0^{-}, \lambda\right)$ ) were calculated using the slope and intercept by fitting the least-squares linear equation to the logtransformed upwelled radiance versus $z$ for MALINA, ICESCAPE2010, and ICESCAPE2011 data. The depth interval was chosen following the method described by Antoine et al. (2013). Briefly, a centered depth z0 and $+/-\Delta \mathrm{z}$ was first set within homogeneous surface layer. The $\Delta \mathrm{z}$ was then increased to have the best statistical fit but was chosen to be as minimal as possible within the homogeneous surface layer. Data within this depth interval were used to extrapolate $\mathrm{L}_{\mathrm{u}}(\mathrm{z}, \lambda)$ to $\mathrm{L}_{\mathrm{u}}\left(0^{-}, \lambda\right)$. For Tara data, loess extrapolation was performed. The remote sensing reflectance, $R_{\mathrm{rs}}(\lambda)$ is defined to be equal to $0.54 L_{u}\left(0^{-}, \lambda\right) / E_{s}(\lambda)$, where $\lambda$ indicates wavelength. In the present study, $R_{\mathrm{rs}}(\lambda)$ at six wavelengths (i.e, 412, 443, 490, 532, 555, and $670 \mathrm{~nm}$ corresponding approximately to the ocean color bands of the Moderate-Resolution Imaging Spectroradiometer (MODIS) onboard the Aqua satellite, Aqua/MODIS) were used to derive $a_{\mathrm{CDOM}}(\lambda)$ at $443 \mathrm{~nm}$ using gsmA algorithm. Prior to analysis, we removed the water Raman contribution to $R_{\mathrm{rs}}(\lambda)$ using the method of Lee et al. (2013). The impact of Raman scattering on $R_{\mathrm{rs}}(\lambda)$ data is examined in Appendix A.1.

\subsection{Satellite ocean color data}

\subsubsection{Match-up analysis}

Aqua/MODIS $R_{r s}(\lambda)$ data $(\lambda=412,443,488,531,555$, and $667 \mathrm{~nm} ; 15 \mathrm{~nm}$ and $10 \mathrm{~nm}$ FWHM for 412-443 and 488-667 nm, respectively) were obtained from the NASA Ocean Biology Processing Group (OBPG) satellite to in situ validation system (Bailey and Werdell, 2006; http://seabass.gsfc.nasa.gov/search). In this study, data from two different reprocessing versions (R2013.1 and R2014.0, respectively) were used to evaluate $\mathrm{a}_{\mathrm{CDOM}}(443)$ retrievals using gsmA algorithm. 

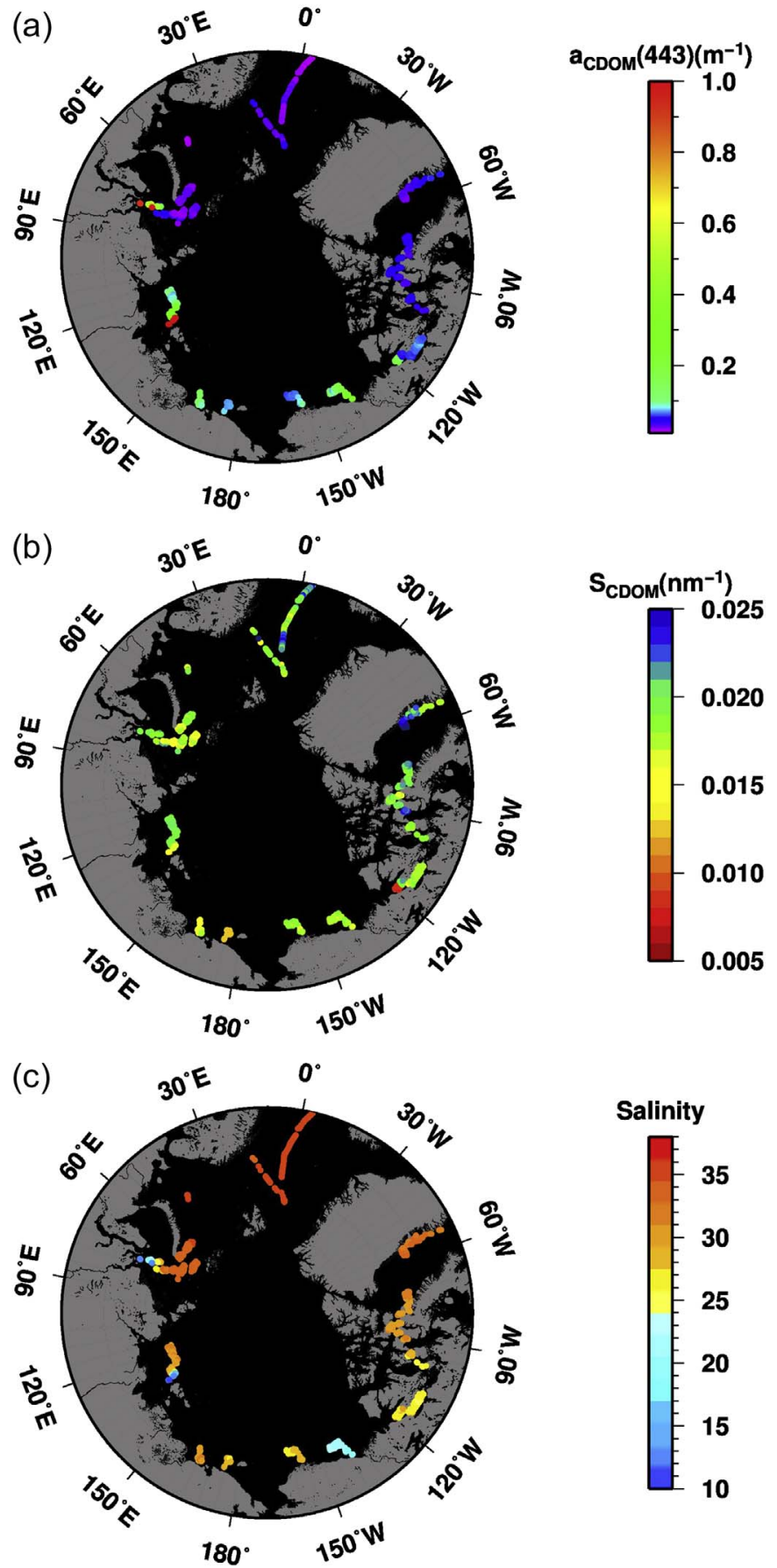

Fig. 2. Spatial distribution map of (a) $\mathrm{a}_{\mathrm{CDOM}}(443)\left(\mathrm{m}^{-1}\right)$, (b) $\mathrm{S}_{\mathrm{CDOM}}\left(\mathrm{nm}^{-1}\right)$, and (c) salinity.

Knowing that Aqua/MODIS has issues with radiometric degradation since 2011 [https://oceancolor.gsfc.nasa.gov/reprocessing/r2014/ aqua/], we chose to include two Aqua/MODIS reprocessing data sets so as to examine how this degradation - and any residual calibration errors and differences that might persist between and within the two processings - might influence our results. No such a radiometric issue has been currently widely revealed for NPP/VIIRS, so the latest data were used in the present study.

$\mathrm{a}_{\mathrm{CDOM}}(443)$ was retrieved by optimizing the difference between measured $R_{r s}(\lambda)$ and $R_{r s}(\lambda)$ calculated using absorption (including unknown $\mathrm{a}_{\mathrm{CDOM}}(443)$ ) and backscattering coefficients, and coefficients associated with geometry of the sun. The Aqua/MODIS-derived $\mathrm{a}_{\mathrm{CDOM}}(443)$ estimates were then directly compared to in situ ac-s
$\mathrm{a}_{\mathrm{CDOM}}(443)$ measurements and the performance of the algorithm was evaluated individually for each processing version. We used data within $+/-3 \mathrm{~h}$ from satellite overpass within solar and sensor zenith angles of 74 and $56^{\circ}$, respectively for this match-up analysis (Bailey and Werdell, 2006; IOCCG, 2015). To be consistent with in situ C-OPS data, the water Raman contribution to satellite-derived $R_{\mathrm{rs}}(\lambda)$ was removed prior to the analysis using the method presented by Lee et al. (2013).

\subsubsection{Estimating DOC concentration from space}

To illustrate spatio-temporal variability in satellite-derived DOC concentrations in Arctic river mouths, Aqua/MODIS Level 2 (L2) $R_{r s}(\lambda)$ swath images at $1-\mathrm{km}$ nadir spatial resolution were obtained from the NASA ocean color website (http://oceandata.sci.gsfc.nasa.gov/MODISAqua/L2). Cloud-free swath images were selected and were used to retrieve $\mathrm{a}_{\mathrm{CDOM}}(443)$ using gsmA algorithm. Because of the polar orbit of earth observing satellites, several swath images are available per day at polar regions. Swath images within $2 \mathrm{~h}$ around solar noon were used to make a daily composite $\mathrm{a}_{\mathrm{CDOM}}(443)$ image at $1 \mathrm{~km}$ spatial resolution. By applying an empirical relationship between DOC concentrations and $\mathrm{a}_{\mathrm{CDOM}}(443)$ to satellite-derived CDOM absorption (described in Section 3.2), we estimated DOC concentrations for river-influenced coastal waters. The uncertainty in our estimates of DOC concentrations was determined according to sensitivity analysis as described in Appendix A.2.

\subsection{Evaluation functions}

We used evaluation functions proposed by Bailey and Werdell (2006) to evaluate the performance of the retrievals of $\mathrm{a}_{\mathrm{CDOM}}(443)$ using gsmA algorithm applied to in situ or satellite $R_{r s}(\lambda)$ data. They include median of satellite to in situ ratio (Rt), the semi-interquantile range (SIQR), the median absolute percent error (MPE), and root mean square error (RMSE) defined as follows:

$\mathrm{Rt}=\operatorname{median}\left(\frac{\mathrm{X}^{\mathrm{mod}}}{\mathrm{X}^{\text {obs }}}\right)$

$\mathrm{SIQR}=\frac{\mathrm{Q}_{3}-\mathrm{Q}_{1}}{2}$

$\operatorname{MPE}=\operatorname{median}\left(100 *\left|\frac{\mathrm{X}^{\mathrm{mod}}-\mathrm{X}^{\mathrm{obs}}}{\mathrm{X}^{\mathrm{obs}}}\right|\right)$

RMSE $=\sqrt{\frac{\sum_{n=1}^{N}\left[\mathrm{X}^{\text {mod }}-\mathrm{X}^{\mathrm{obs}}\right]^{2}}{N}}$

where $\mathrm{X}^{\mathrm{mod}}$ and $\mathrm{X}^{\text {obs }}$ represent vectors of estimated and measured $\mathrm{a}_{\mathrm{CDOM}}(443)$, respectively. $\mathrm{Q}_{1}$ and $\mathrm{Q}_{3}$ represent the 25th and 75th percentile, respectively. In addition, model II linear regression based on ranged major axis (RMA) method was performed following Legendre and Legendre (1998). In this study, log-transformed data were used for these evaluations except for $R_{r s}(\lambda)$ data (see Appendix A.1).

\section{Results and discussion}

\subsection{CDOM absorption characteristics at the Pan-Arctic Ocean}

CDOM absorption values fall in the range of the M2014 database (Fig. 1b). The frequency of high $\mathrm{a}_{\mathrm{CDOM}}(443)$ values $\left(>1.0 \mathrm{~m}^{-1}\right)$ was somewhat higher compared to M2014, due mainly to higher CDOM contents observed in the Yenisei and Ob River mouths (Aas et al., 2002; Hessen et al., 2010; Heim et al., 2014; Matsuoka et al., 2014). Overall, lower median $\mathrm{a}_{\mathrm{CDOM}}(443)$ values were observed in the present study compared to the M2014 $\left(0.037\right.$ and $0.058 \mathrm{~m}^{-1}$ for the Tara and the M2014, respectively; Table 2). $\mathrm{S}_{\mathrm{CDOM}}$ values in this study were similarly distributed to those in the M2014 database (Fig. 1c; medians of $\mathrm{S}_{\mathrm{CDOM}}$ 


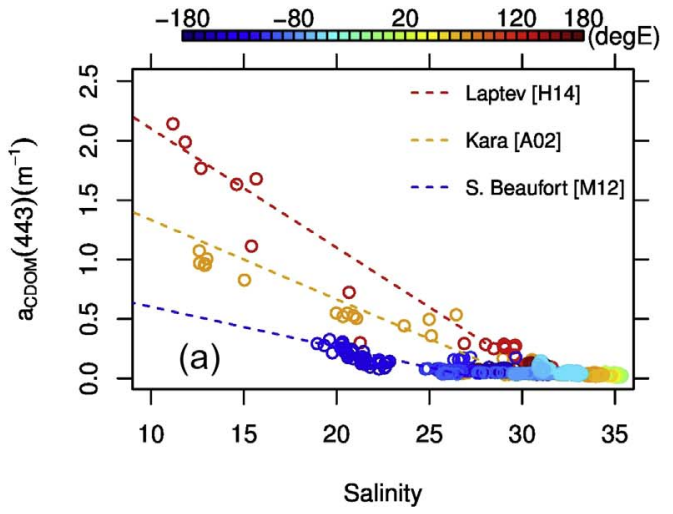

values for this study and the M2014 database were 0.0187 and $0.0183 \mathrm{~nm}^{-1}$, respectively; Table 2). These results confirm that CDOM measurements obtained during the Tara Arctic expedition are representative of the range observed in the Arctic Ocean.

Spatial distribution patterns of CDOM absorption properties were examined in a wide spatial coverage including both oceanic and coastal waters (Fig. 2). In the Norwegian and Greenland Seas, and west coast of Greenland, $\mathrm{a}_{\mathrm{CDOM}}(443)$ values were remarkably low $\left(<0.1 \mathrm{~m}^{-1}\right)$. This result is consistent with that reported by Kirk (1994). In contrast, high $\mathrm{a}_{\mathrm{CDOM}}(443)$ values were observed in river-influenced coastal areas of the Siberian side (up to $2.1 \mathrm{~m}^{-1}$ ) and on the Canadian side (up to $0.6 \mathrm{~m}^{-1}$ ). The high $\mathrm{a}_{\mathrm{CDOM}}(443)$ values corresponded with low salinity in these waters (Fig. 2c). Indeed, $\mathrm{a}_{\mathrm{CDOM}}(443)$ values were tightly correlated with salinity for all river mouths (Fig. 3a), indicating that high CDOM contents were delivered by rivers. This type of conservative behavior of the $\mathrm{a}_{\mathrm{CDOM}}(443)$ versus salinity relationship in river-influenced coastal waters has been reported elsewhere (e.g., Jerlov, 1976; Monahan and Pybus, 1978; Nieke et al., 1997; Bélanger et al., 2006; Retamal et al., 2007; Mannino et al., 2008; Matsuoka et al., 2012). For $\mathrm{WAO}$, the $\mathrm{a}_{\mathrm{CDOM}}(443)$ versus salinity relationship established in September in the present study was similar to the one obtained in the southern Beaufort Sea in August reported by Matsuoka et al. (2012) (blue dashed line in Fig. 3a; $p>0.5$ ). Our $\mathrm{a}_{\mathrm{CDOM}}(443)$-salinity relationship for the Laptev Sea obtained in August was also similar to that obtained from August to September and reported by Heim et al. (2014). Our $\mathrm{a}_{\mathrm{CDOM}}(443)$ versus salinity relationship obtained in July for the Kara Sea was close to the relationship observed in September by Aas et al. (2002), although the slope was lower in the present study. These results confirm previous studies; while the conservative physical mixing plays a major role in the behavior of $\mathrm{a}_{\mathrm{CDOM}}$ (443)-salinity relationship at low salinity $(<25)$, this relationship can vary seasonally and interannually (particularly for the case of Kara Sea). Data points that deviated from the mixing line likely come from waters experiencing degradation of organic matter due to either physical (Alling et al., 2010) and/or biogeochemical processes (Ortega-Retuerta et al., 2012; Asmala et al., 2014; Matsuoka et al., 2015).

The spatial distribution pattern of $\mathrm{S}_{\mathrm{CDOM}}$ was more variable than $\mathrm{a}_{\mathrm{CDOM}}(443)$ (Fig. $3 \mathrm{~b}$ ). Given that $\mathrm{S}_{\mathrm{CDOM}}$ is influenced by complex physico-biogeochemical effects (i.e., mixing, photo-bleaching, microbial activity; Nelson and Siegel, 2002), it is difficult to explain the spatial variability using $\mathrm{S}_{\mathrm{CDOM}}$ and salinity alone. Instead, $\mathrm{S}_{\mathrm{CDOM}}$ versus $\mathrm{a}_{\mathrm{CDOM}}(443)$ relationship could provide a rough idea of characteristics of dissolved organic matter (Stedmon et al., 2011) when compared to that in the literature. For example, Matsuoka et al. (2011) (M11) using data obtained from oceanic waters suggested photo-bleaching is a major effect controlling $\mathrm{S}_{\mathrm{CDOM}}$ versus $\mathrm{a}_{\mathrm{CDOM}}(443)$ relationship. Our data points showing $\mathrm{a}_{\mathrm{CDOM}}(443)$ lower than $0.1 \mathrm{~m}^{-1}$ are generally distributed within the $95 \%$ confidence interval (gray lines in Fig. 3b). At $\mathrm{a}_{\mathrm{CDOM}}(443)>0.1 \mathrm{~m}^{-1}$ (obtained from coastal environments), most of our data fall within the range obtained in coastal waters by Matsuoka
Fig. 3. (a) $\mathrm{a}_{\mathrm{CDOM}}(443)$ versus salinity relationship with colors varying according to longitude.

Regressions by Aas et al. (2002) for Kara Sea (A02), Heim et al. (2014) for Laptev Sea (H14), and Matsuoka et al. (2012) for Southern Beaufort Sea (M12) are also shown for comparison. (b) $\mathrm{S}_{\mathrm{CDOM}}\left(\mathrm{nm}^{-1}\right)$ versus $\mathrm{a}_{\mathrm{CDOM}}(443)$ relationship. $95 \%$ confidence intervals of regressions reported by Matsuoka et al. (2011) for oceanic waters (gray lines) and Matsuoka et al. (2012) for coastal waters (black dashed lines) of the western Arctic Ocean are also shown for comparison. et al. (2012) (M12: black dashed line in Fig. 3b). These results suggest that a majority of our data can be explained by river-influence and/or photo-bleaching. Data points outside M11 and M12 might be attributed to either sea ice melt (Amon, 2004; Matsuoka et al., 2012), microbial effect (Matsuoka et al., 2015), physical mixing (Retamal et al., 2008), or their combined effect. Further work using chemical identification technique is required to ascertain these effects.

The Raman-corrected CDOM fluorescence at $405 \mathrm{~nm}$ of the ALFA was highly correlated with the CDOM absorption measurement at $405 \mathrm{~nm}\left(r^{2}=0.99\right.$; Fig. 4). This result highlights the informative potential of CDOM fluorescence, the technology of choice on autonomous platforms. Note that the relationship between CDOM absorption at $514 \mathrm{~nm}$ and the Raman-corrected CDOM fluorescence stimulated at $514 \mathrm{~nm}$ were less robust $\left(r^{2}=0.88\right.$; plot not shown), possibly affected by the spectral overlap between CDOM and phycobiliprotein (PBP) pigment fluorescence bands (Chekalyuk and Hafez, 2008). The ratios of $\mathrm{a}_{\mathrm{CDOM}}\left(\lambda_{1}\right)$ to $\mathrm{F}_{\mathrm{CDOM}}\left(\lambda_{2}\right)\left(\lambda_{1}\right.$ or $\lambda_{2}$ represents either $405 \mathrm{~nm}$ or $\left.514 \mathrm{~nm}\right)$ versus $\mathrm{S}_{\mathrm{CDOM}}$ did not show clear pattern in this study (not shown). While corresponding absorption and fluorescence data were obtained only at two wavelengths in this study, hyper-spectral fluorescence measurements combined with coincident absorption measurements may provide potential for characterizing both sources and compositions of CDOM (e.g., Stedmon and Markager, 2005; Guéguen et al., 2012; Para et al., 2012; Goncalves-Araujo et al., 2015).

\subsection{Monitoring DOC concentrations from satellite remote sensing}

There is growing concern regarding the modifications in DOC fluxes

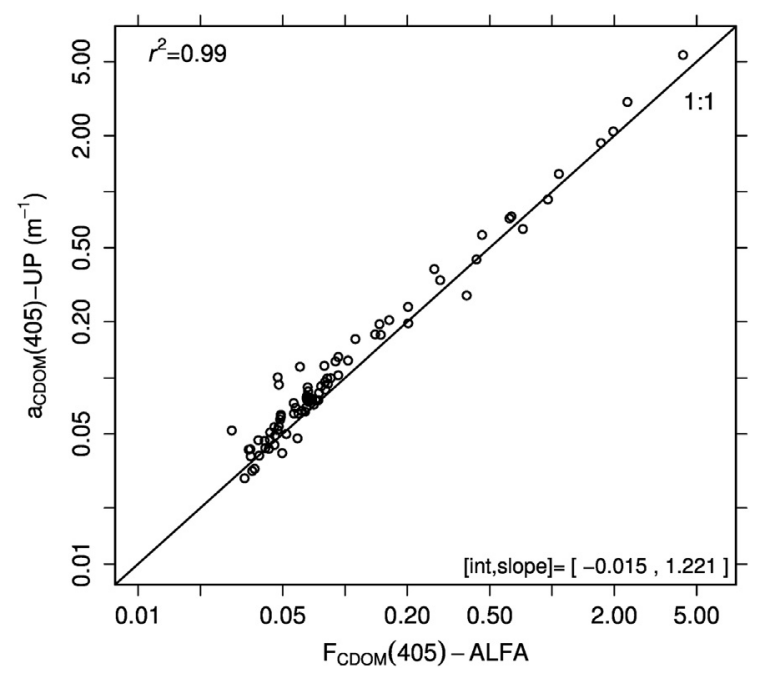

Fig. 4. Relationship between $\mathrm{a}_{\mathrm{CDOM}}(405)$ (measured using an UltraPath) and Ramancorrected $\mathrm{CDOM}$ fluorescence $\left(\mathrm{F}_{\mathrm{CDOM}}(\lambda)\right)$ stimulated at $405 \mathrm{~nm}$ (ALFA measurements). 


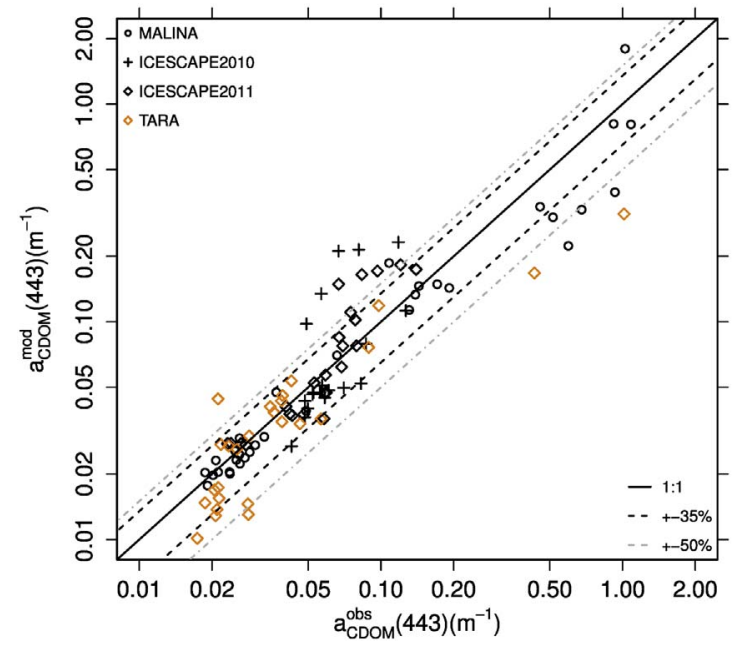

Fig. 5. Evaluation of $\mathrm{a}_{\mathrm{CDOM}}(443)$ estimated using in situ $R_{r s}(\lambda)$ data obtained from a COPS ( $\mathrm{a}_{\mathrm{CDOM}}^{\mathrm{mod}}(443), \mathrm{m}^{-1}$ ) against in situ measurements ( $\mathrm{a}_{\mathrm{CDOM}}^{\mathrm{obs}}(443), \mathrm{m}^{-1}$ ).

originating from permafrost thaw and the consequences in biogeochemical processes in Arctic coastal waters, particularly its microbial consumption and the potential release of carbon dioxide $\left(\mathrm{CO}_{2}\right)$ into the atmosphere (IPCC, 2007, 2013; McGuire et al., 2009). DOC concentrations are highly correlated with CDOM absorption for river-influenced coastal waters (e.g., Matsuoka et al., 2012, 2014; Heim et al., 2014). In addition to mechanisms controlling CDOM absorption properties (see Section 3.1), tracing these variations temporally and geographically is important to better understand the carbon cycle.

To trace DOC dynamics, we recently developed a semi-analytical algorithm for Arctic waters (i.e., gsmA algorithm) that can be applied to satellite ocean color $R_{r s}(\lambda)$ data such as those provided by Aqua/MODIS and the Suomi National Polar-orbiting Partnership (NPP) Visible Infrared Radiometer Suite (VIIRS) (Matsuoka et al., 2013, 2014). This algorithm includes two steps: 1) first retrieving $\mathrm{a}_{\mathrm{CDOM}}(443)$ value and then 2) estimating DOC concentrations. The present re-evaluation of this algorithm using in situ $R_{r s}(\lambda)$ (i.e., C-OPS) data obtained from both EAO and WAO shows that $\mathrm{a}_{\mathrm{CDOM}}(443)$ value can be derived with 7.1, 0.176, and 0.060 for MPE, RMSE, and SIQR, respectively (Fig. 5; Table 3). Rt and slope were close to 1 and coefficient of determination was high $\left(r^{2}=0.86\right)$. In addition, a direct comparison of in situ measurements with satellite-derived $\mathrm{a}_{\mathrm{CDOM}}(443)$ (i.e., match-up analysis) demonstrates that the MPEs of $\mathrm{a}_{\mathrm{CDOM}}(443)$ estimate for the two Aqua/ MODIS processing versions (R2013.1 and R2014.0) are 9.0 and 11.6\%, respectively (Fig. 6, Table 3). Other statistical measures also show the reasonable $\mathrm{a}_{\mathrm{CDOM}}(443)$ estimate (Rt close to 1 , reasonable SIQR and RMSE). It is interesting to note that slope for R2014.0 reduced and was closer to 1, while MPE and RMSE somewhat increased. In either case, given that different on-orbit temporal calibration were applied within the two different reprocessing versions, the $3 \%$ differences in the $\mathrm{a}_{\mathrm{CDOM}}(443)$ retrieval are small, indicating that residual errors in satellite instrument calibrations do not strongly influence our results. A MPE of 8.5\% was obtained for NPP/VIIRS. All these results confirm the reasonable performance of gsmA algorithm for Arctic waters. Note that coefficients of determination for all satellite sensors are relatively low and the slope for R2013.1 is higher than 1, due mainly to the small dynamic range of $\mathrm{a}_{\mathrm{CDOM}}(443)$ used for the analysis (Table 3 ).

To estimate concentrations of DOC using satellite ocean color data, a robust DOC versus $\mathrm{a}_{\mathrm{CDOM}}(443)$ relationship must be established. It is not clear if a DOC versus $\mathrm{a}_{\mathrm{CDOM}}(443)$ relationship would differ between EAO and WAO. Matsuoka et al. (2014), using a limited number of data, suggested that the difference in the relationship might be attributed to the difference in the watershed.

To answer this question, we used publicly available DOC and $\mathrm{a}_{\mathrm{CDOM}}(443)$ data, recently compiled by Massicotte et al. (in press), in addition to our data obtained from the TARA cruise. This represents the maximal number of the data currently available for the Arctic Ocean. Analysis of covariance (ANCOVA) indeed showed that there is no significant difference in the DOC versus $\mathrm{a}_{\mathrm{CDOM}}(443)$ relationship between EAO and WAO $(p=0.41)$. Instead, a single and highly significant correlation was found $\left(r^{2}=0.94, N=115\right)$. Given the fact that watershed is diverse in both North American and Siberian sides of the Arctic Ocean, it suggests that this relationship is likely insensitive to detecting changes in quality of organic matter.

Matsuoka et al. (2014) used a regression published by Walker et al. (2013) (hereafter referred to as W13) to estimate DOC concentrations in EAO. The valid ranges of $\mathrm{a}_{\mathrm{CDOM}}(443)$ and DOC for their measurements (i.e., $\quad 0.39 \mathrm{~m}^{-1}<\mathrm{a}_{\mathrm{CDOM}}(443)<8.4 \mathrm{~m}^{-1}$ and $166 \mu \mathrm{M}<\mathrm{DOC}$ $1660 \mu \mathrm{M}$, respectively) are restricted to high values compared to those in the present study (dashed curve in Fig. 7). The main reason is that the authors obtained their regression using data in river pilot stations which were located a few hundred to $>600 \mathrm{~km}$ upstream from the river mouths (Amon et al., 2012; Walker et al., 2013), restricting the applicability of the relationship to river waters. This regression is replaced here by that from the present study.

To evaluate the confidence in satellite-derived DOC concentrations, the uncertainty in our estimates of DOC concentrations was determined by performing a sensitivity analysis as described in Appendix A.2. This analysis suggested that DOC concentrations can be estimated with an average uncertainty of $28 \%$. This uncertainty is reasonable given the large dynamic range of DOC in the coastal Arctic waters (39-732 $\mu \mathrm{M}$ in the present study).

Ocean color data for Polar Regions inevitably suffer from frequent cloud cover. However, because of the polar orbit of the earth-observing satellites, several satellite images are available per day for Polar Regions (i.e., this results in a higher density of polar data compared to lower latitudes). This fact compensates somewhat the issue of cloud cover (IOCCG, 2015; Doxaran et al., 2015; Matsuoka et al., 2016). This is illustrated in daily DOC concentration images shown in Fig. 8 and 9 using the DOC versus $\mathrm{a}_{\mathrm{CDOM}}(443)$ relationship established here within the valid ranges of the two variables used in the regression. A spatiotemporal variability in DOC concentrations is clearly observed. Ranges of the DOC estimates (5 and 95\% percentiles) suggested that both the low and high ends of DOC concentrations vary from time to time (Table 4). For example, $116 \mu \mathrm{M}$ and $289 \mu \mathrm{M}$ (low and high ends of DOC estimates, respectively) were observed in the Laptev (LP) sea on 19 July 2011 , and these values increased significantly (150 and $341 \mu \mathrm{M}$ for low and high -end of DOC estimates, respectively) on 10 August 2011. On 20 September 2011, the low- and high-end values decreased (114 and

Table 3

Statistics of $\mathrm{a}_{\text {CDOM }}(443)$ estimated using in situ $R_{r s}(\lambda)$ (C-OPS) and satellite (Aqua/MODIS and NPP VIIRS) data using the gsmA algorithm (Matsuoka et al., 2013).

\begin{tabular}{|c|c|c|c|c|c|c|c|c|c|}
\hline Retrievals & Rt & SIQR & \%MPE & RMSE & Slope & Intercept & $r^{2}$ & Range of in situ $\mathrm{a}_{\mathrm{CDOM}}(443)$ & $N$ \\
\hline $\mathrm{a}_{\mathrm{CDOM}}(443) \_\mathrm{C}-\mathrm{OPS}$ & 1.030 & 0.060 & 7.1 & 0.176 & 1.01 & -0.01 & $0.86^{* * * *}$ & $0.012-1.082$ & 103 \\
\hline $\mathrm{a}_{\mathrm{CDOM}}$ (443)_MODIS (R2013.1) & 1.038 & 0.114 & 9.0 & 0.275 & 1.26 & 0.36 & $0.53^{* * *}$ & $0.013-0.100$ & 32 \\
\hline $\mathrm{a}_{\mathrm{CDOM}}(443) \_\mathrm{MODIS}$ (R2014.0) & 1.039 & 0.090 & 11.6 & 0.292 & 1.13 & 0.14 & $0.51^{* * * *}$ & $0.013-0.475$ & 31 \\
\hline $\mathrm{a}_{\text {CDOM }}$ (443)_VIIRS & 0.997 & 0.063 & 8.5 & 0.303 & 0.17 & -1.36 & 0.01 & $0.013-0.101$ & 12 \\
\hline
\end{tabular}

${ }^{* * *} p<0.0001$ 

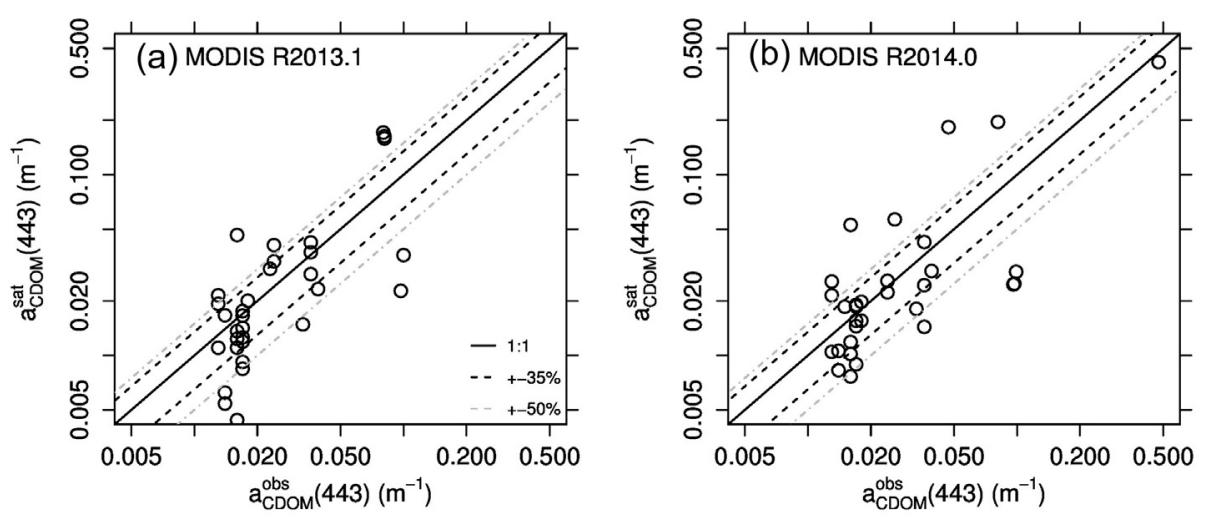

Fig. 6. Match-up results for MODIS
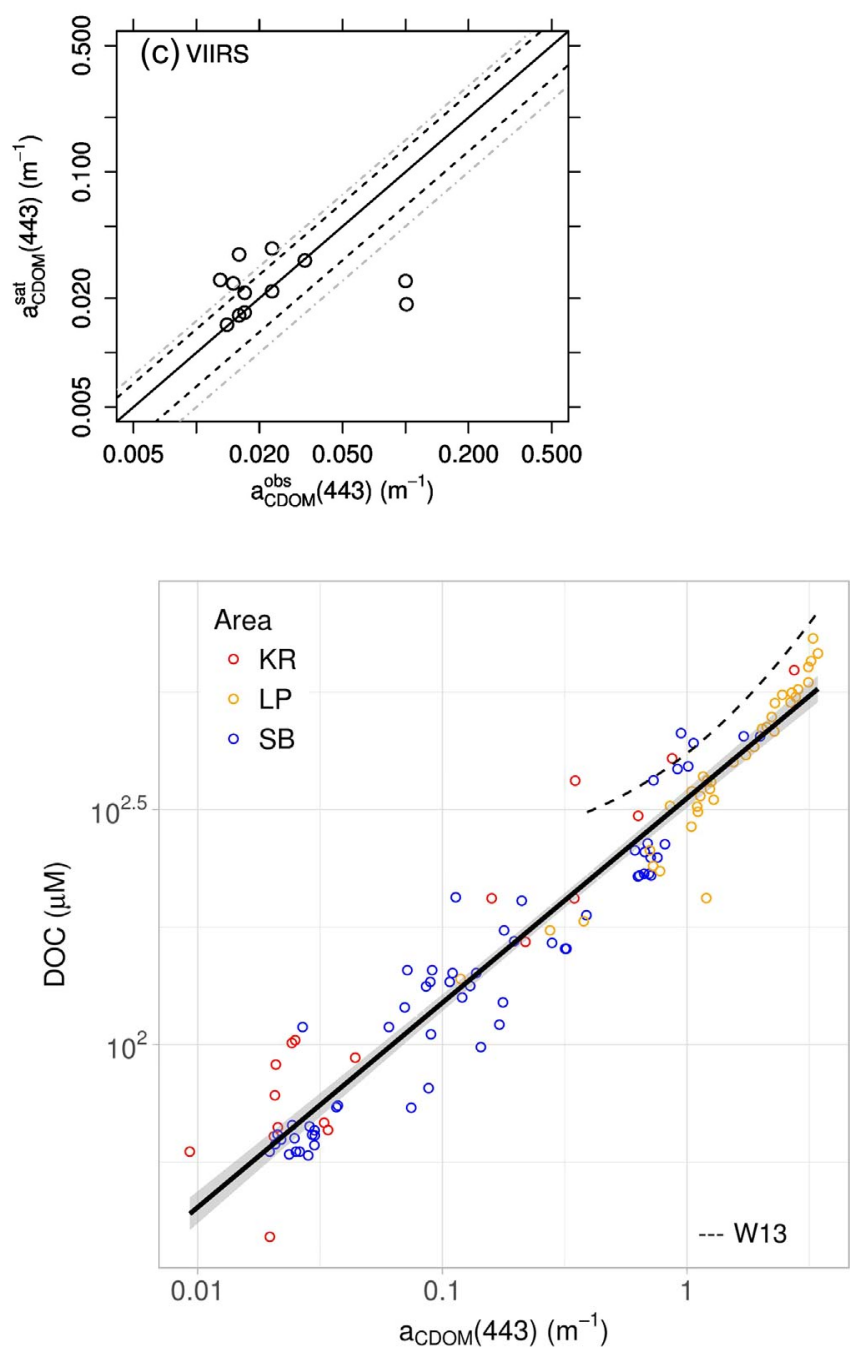

Fig. 7. DOC versus $\mathrm{a}_{\mathrm{CDOM}}(443)$ relationship established using data obtained from Kara (KR, red circles), Laptev (LP, yellow circles), and Southern Beaufort seas (SB, blue cir-

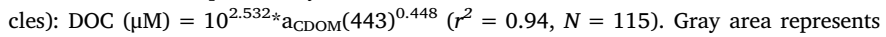
95\% confidence intervals. Regressions by Walker et al. (2013) (W13, dashed curve) are also shown for comparison. (For interpretation of the references to color in this figure legend, the reader is referred to the web version of this article.)

$274 \mu \mathrm{M})$ and were back to similar values as observed on 19 July 2011. In terms of absolute DOC concentrations estimated using satellite ocean color data, our estimates fall within the ones reported in the literature for four and major Arctic river mouths (i.e., Ob', Yenisey, Lena, and Mackenzie river mouths; Amon, 2004; Hessen et al., 2010; Matsuoka et al., 2012; Orek et al., 2013). These results suggest that our approach to obtain DOC concentrations from ocean color data is reasonable,

highlighting that the continuous monitoring of DOC concentrations is now possible with a known uncertainty.

Note that for some images, pixels near river mouths are masked out (for example 10 August 2011 for Lena river mouth on Fig. 8), which points out atmospheric correction problems for river mouths. This problem should be solved in the future using approaches such as those applied by Doxaran et al. (2015) and Matsuoka et al. (2016).

\section{Conclusions}

In the present study, we show that CDOM absorption properties vary significantly in various environments of the Pan-Arctic Ocean using continuous sampling instruments installed in a flow-through mode such as ac-s and ALFA. Our results suggest that establishing the relationship between CDOM absorption and its spectral slope could be useful for examining effects of terrestrial input, photobleaching, and microbial activity as outlined by Stedmon et al. (2011). Combined with spectral CDOM fluorometry, it may help to better understand variability in quality of dissolved organic matter. To facilitate discriminating the biogeochemical effects on CDOM, the optical methods need to be ascertained with a robust technique such as chemical identification.

Match-ups with satellite data demonstrate that CDOM absorption at $443 \mathrm{~nm}$ is derived using satellite ocean color data with an average uncertainty of $12 \%$ (RMSE of $0.3 \mathrm{~m}^{-1}$ ), and DOC concentration is derived with an average uncertainty of $28 \%$. Long-term in situ river discharge data are now publicly available thanks to several organizations (e.g., US Geological Survey, Environment Canada) and international projects such as the Pan-Arctic River Transport of Nutrients, Organic matter, and Suspended sediments (PARTNERS, e.g., Holmes et al., 2012). Satellite ocean color data have accumulated nearly 20 years. When combining these data together, DOC fluxes for river can further be estimated from space. This approach could be used to examine the trend of DOC fluxes in recent decades for Arctic rivers as a consequence of permafrost thaw and increase in river discharge (McGuire et al., 2009; IPCC, 2013).

Satellite estimate of DOC might contribute to investigate recent 

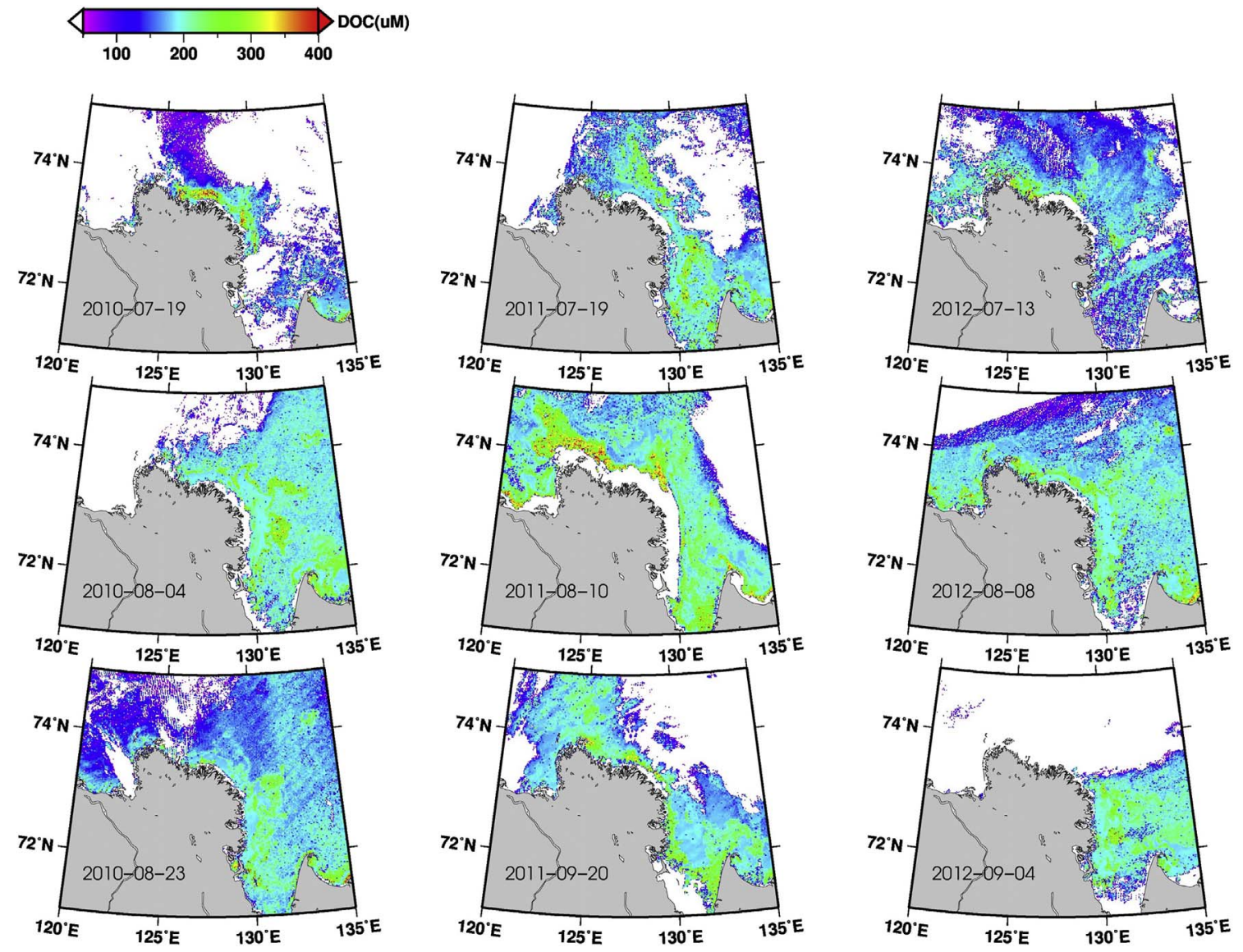

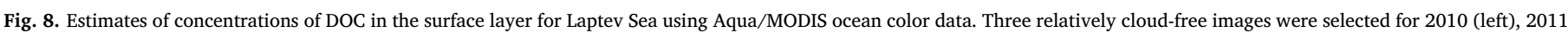
(middle), and 2012 (right). (For interpretation of the references to color in this figure legend, the reader is referred to the web version of this article.)
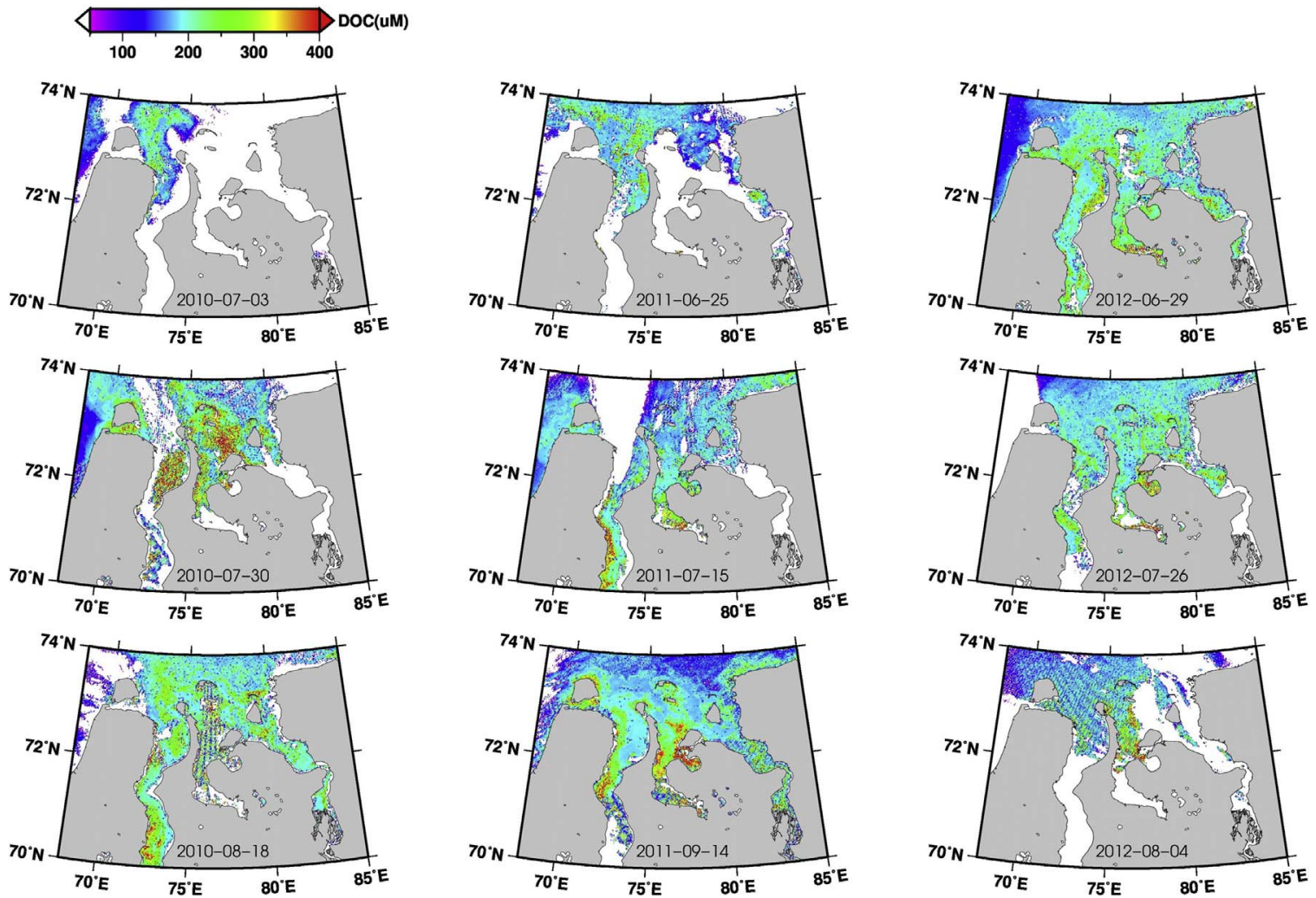

Fig. 9. Same for Fig. 8 but for Kara Sea. Three relatively cloud-free images were selected for 2010 (left), 2011 (middle), and 2012 (right). 
Table 4

Ranges of DOC estimates ( $5 \%$ and 95\% percentiles in $\mu \mathrm{M}$ ) using Aqua/MODIS ocean color data for Kara (KR) and Laptev (LP) seas for some selected (relatively clear-sky) images.

\begin{tabular}{llll}
\hline Ranges of DOC (in $\mu \mathrm{M})$ & 2010 & 2011 & 2012 \\
\hline LP & Jul. 19 & Jul. 19 & Jul. 13 \\
& {$[55,303]$} & {$[116,289]$} & {$[90,255]$} \\
& Aug. 4 & Aug. 10 & Aug. 8 \\
& {$[148,275]$} & {$[150,341]$} & {$[99,258]$} \\
& Aug. 23 & Sep. 20 & Sep. 4 \\
& {$[80,234]$} & {$[114,274]$} & {$[137,266]$} \\
& Jul. 3 & Jun. 25 & Jun. 29 \\
KR & {$[73,277]$} & {$[93,288]$} & {$[107,328]$} \\
& Jul. 30 & Jul. 15 & Jul. 26 \\
& {$[118,445]$} & {$[107,327]$} & {$[148,321]$} \\
& Aug. 18 & Sep. 14 & Aug. 4 \\
& {$[143,380]$} & {$[116,376]$} & {$[94,343]$} \\
\hline
\end{tabular}

modifications in Arctic DOC cycling and its impact on the global $\mathrm{CO}_{2}$ flux when combined with in situ observations and a numerical model. Regarding in situ observations, recent findings showed that old permafrost-origin DOC is much more labile than what was previously thought and thus can be rapidly utilized by heterotrophic bacteria (Mann et al., 2015; Spencer et al., 2015). This apparently contradictory fact is likely explained by high levels of aliphatics included in the permafrost that is rapidly utilized by microbes (Spencer et al., 2015). This result implies a possible increase in $\mathrm{CO}_{2}$ release to the atmosphere by bacteria. Regarding numerical model, reasonable estimates of organic matter have been achieved in recent years (Manizza et al., 2009; Le Fouest et al., 2013). A more accurate prediction can be achieved by introducing satellite DOC estimates in an assimilation mode to constrain models. In addition, long-term in situ data (e.g., microbial and phytoplanktonic data) have been accumulated particularly in the Beaufort Sea to examine ecosystem changes in this region under climate changes (e.g., Li et al., 2009; Comeau et al., 2011), which has led to improve the performance of a numerical model that includes the microbial loop (Le Fouest et al., 2013). With the associated uncertainties, the Arctic Ocean can be better assessed. This important task remains to be made in further studies.

\section{Acknowledgements}

The authors thank technical support by M. Picheral, C. Dimier, C. Marec, Tara Oceans Consortium, Coordinators, Tara Oceans Expedition, Tara crew, and participants during the Tara Oceans Polar Circle expedition. Part of CDOM absorption measurements were done by $\mathrm{T}$. Leeuw, J. Ferland, and A. Chase. All instruments maintenance and COPS deployment were conducted by M. Picheral, C. Marec, and S. Morisset. Processing of C-OPS data was conducted by G. Bécu. DOC concentrations were determined and provided by R. Benner and $\mathrm{Y}$. Shen. Corresponding Tara barcodes for CDOM and DOC data ranged from TARA_G100019139 to TARA_P100004864. Salinity data from the flow-through system were obtained from https://doi.pangaea.de/10. 1594/PANGAEA.836320. The ALFA instrument was provided by WET Labs, Inc.

This study was conducted as part of the MALINA Scientific Program funded by ANR (Agence nationale de la recherche), INSU-CNRS (Institut national des sciences de l'univers - Centre national de la recherche scientifique), CNES (Centre national d'études spatiales), ESA (European Space Agency), and National Aeronautic Space Agency (NASA). Support to bio-optical measurements during the expedition was provided by NASA through grant \#NNX13AE58G to EB and LKB and by ESA through grant \#L13I220 to AB. Part of this study was also funded by the Japan Aerospace Exploration Agency (JAXA) GCOM-C project through grant \#16RSTK-007867 to AM. We also thank a joint contribution to the research programs of UMI Takuvik, ArcticNet (Network Centres of Excellence of Canada) and the Canada Excellence Research Chair in Remote Sensing of Canada's New Arctic Frontier. We thank three anonymous reviewers who contributed to improve the quality of the manuscript. We thank E. Rehm for insightful discussions regarding Raman scattering.

\section{Appendix A.1. Effect of Raman scattering on $R_{r s}(\lambda)$ data and $a_{\text {CDOM }}(443)$ estimate}

We examined the effect of Raman scattering on $R_{r s}(\lambda)$ data and $\mathrm{a}_{\mathrm{CDOM}}(443)$ estimate. The evaluation functions described in Section 2.3 were used for in situ $R_{r s}(\lambda)$ data with ${ }_{c o r} R_{r s}(\lambda), \mathrm{sr}^{-1}$ ) and without Raman correction ( $\left.{ }_{\mathrm{obs}} R_{r s}(\lambda), \mathrm{sr}^{-1}\right)$; cor $R_{r s}(\lambda)$ and obs $R_{r s}(\lambda)$ can be regarded as $\mathrm{X}^{\text {mod }}$ and $\mathrm{X}^{\text {obs }}$,

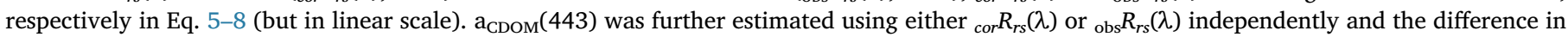
the $\mathrm{a}_{\mathrm{CDOM}}(443)$ estimates was evaluated as described in Section 2.3.

Results showed that the correction removed the effect of Raman scattering on $R_{r s}(\lambda)$ as shown in Rt and regression slopes < 1:1 line (Table A1). The corresponding MPE of $R_{r s}(\lambda)$ ranged from about $2 \%$ at $412 \mathrm{~nm}$ to about $4 \%$ at $670 \mathrm{~nm}$. The SIQR varied from $0.002 \mathrm{sr}^{-1}$ at $412 \mathrm{~nm}$ to $0.010 \mathrm{sr}^{-1}$ at $670 \mathrm{~nm}$. Given high quality of $R_{r s}(\lambda)$ (the error $<5 \%$ is targeted) is required to derive meaningful geophysical values, this result suggests nonnegligible contribution of Raman scattering on $R_{r s}(\lambda)$ data.

Independent to the above-mentioned analysis, we performed a sensitivity analysis to examine the Raman effect on $R_{r s}(\lambda)$ using a radiative transfer simulation (Hydrolight version 5.3, hereafter referred to as HE5.3). Simulations were done for a typical Arctic waters (chl $a$ concentration $=0.1 \mathrm{mg} \mathrm{m}^{-3}, 0.01 \mathrm{~m}^{-1}<\mathrm{a}_{\mathrm{CDOM}}(443)<0.04 \mathrm{~m}^{-1}$, and $0.1 \mathrm{~g} \mathrm{~m}^{-3}<$ suspended particle matter concentration $<1.0 \mathrm{~g} \mathrm{~m}^{-3}$ ) based on Arctic optical parameters documented by Matsuoka et al. (2011, the present study), which produced HE5.3-simulated $R_{r s}(\lambda)$ including and without Raman effect. Result showed that Raman scattering has an impact on $R_{r s}(\lambda)$ more than $3 \%$ particularly in the green-red spectral domain. This result is consistent with our analysis.

Table A1

Summary of the Raman effect on $R_{r s}(\lambda)$ data and $\mathrm{a}_{\mathrm{CDOM}}(443)$ estimate.

\begin{tabular}{|c|c|c|c|c|c|c|c|c|}
\hline Variable & $\mathrm{Rt}$ & SIQR & \%MPE & Slope & Intercept & $r^{2}$ & RMSE & $N$ \\
\hline$R_{r s}(412)$ & 0.981 & 0.002 & 1.95 & 0.976 & 0.000 & $1.00^{* * * *}$ & $1.00 \mathrm{E}-04$ & 103 \\
\hline$R_{r s}(443)$ & 0.978 & 0.002 & 2.20 & 0.976 & 0.000 & $1.00^{* * * *}$ & $1.00 \mathrm{E}-04$ & 103 \\
\hline$R_{r s}(490)$ & 0.973 & 0.006 & 2.73 & 0.986 & 0.000 & $1.00^{* * * *}$ & $1.00 \mathrm{E}-04$ & 103 \\
\hline$R_{r s}(532)$ & 0.966 & 0.008 & 3.38 & 0.986 & 0.000 & $1.00^{\text {**** }}$ & $1.00 \mathrm{E}-04$ & 103 \\
\hline$R_{r s}(555)$ & 0.963 & 0.010 & 3.71 & 0.984 & 0.000 & $1.00^{* * * *}$ & $1.00 \mathrm{E}-04$ & 103 \\
\hline$R_{r s}(670)$ & 0.962 & 0.010 & 3.85 & 0.981 & 0.000 & $1.00^{\text {**** }}$ & $1.00 \mathrm{E}-04$ & 103 \\
\hline$a_{\text {СDOM }}(443)$ & 0.999 & 0.013 & 1.32 & 0.987 & -0.012 & $0.93^{* * * *}$ & 0.237 & 103 \\
\hline
\end{tabular}

${ }^{* * *} p<0.0001$. 


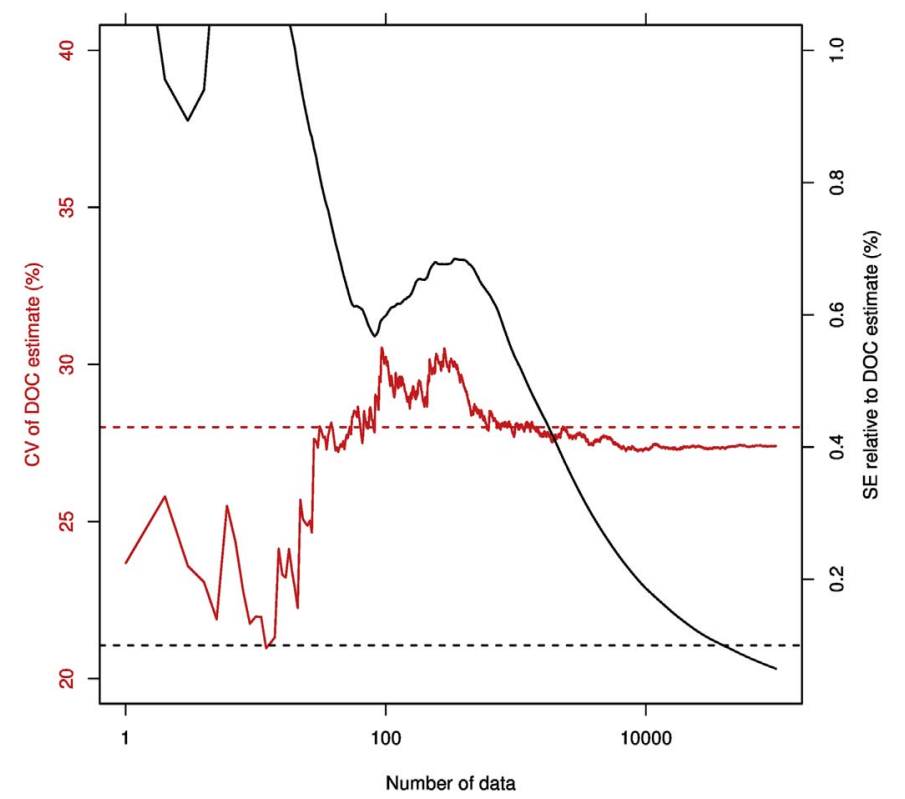

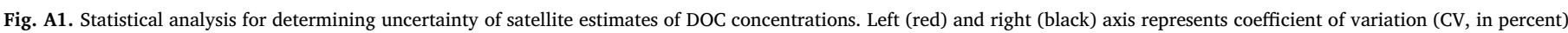

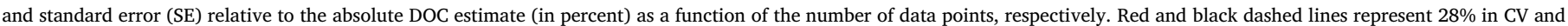
$0.1 \%$ in SE relative to DOC estimates, respectively. (For interpretation of the references to color in this figure legend, the reader is referred to the web version of this article.)

The significant contribution of Raman scattering on $R_{r s}(\lambda)$ for Arctic waters is somewhat contradictory because this effect is more pronounced in typical Morel and Prieur (1977)'s case 1 water than in case 2 waters (Morel and Gentili, 1991, 1993; Gordon, 1999); Arctic waters are often classified as case 2 water due to high proportion of CDOM absorption relative to scattering (Antoine et al., 2013; Matsuoka et al., 2011, 2014). However, it is logical that upwelling radiance in the water column within the remote sensing domain (up to $37^{\circ}$ from the sun zenith) is contributed by Raman scattering when single scattering prevails in case 2 water (Loisel and Morel, 2001).

A question then arises if the Raman effect has an impact on $\mathrm{a}_{\mathrm{CDOM}}(443)$ estimate. By applying gsmA algorithm to either ${ }_{\text {cor }} R_{r s}(\lambda)$ or ${ }_{\text {obs }} R_{r s}(\lambda)$, we obtained MPE and SIQR values of 1.32 and 0.013 , respectively for the $\mathrm{a}_{\mathrm{CDOM}}(443)$ estimates. It was shown that Rt and slope of the regression for $\mathrm{a}_{\mathrm{CDOM}}(443)$ with ${ }_{\text {cor }} R_{r s}(\lambda)$ versus the one with ${ }_{\text {obs }} R_{r s}(\lambda)$ relationship were still close to 1 and the corresponding $r^{2}$ was high $\left(r^{2}=0.93, N=103\right)$. This result suggests the minor impact of Raman scattering on $\mathrm{a}_{\mathrm{CDOM}}(443)$ estimate when using gsmA algorithm. It should be noted however that the few percent difference in $R_{r s}(\lambda)$ could have a significant impact on a geophysical value when using other algorithms. This needs to be determined in the further work.

\section{Appendix A.2. Uncertainty analysis}

The uncertainty in estimates of DOC concentrations is required to provide a sense of confidence of the estimates. A similar statistical analysis performed by Matsuoka et al. (2016) was adopted in the present study. In essence, mean and the standard deviation of the intercept (int) and the slope (slo) for the log-transformed DOC versus $\mathrm{a}_{\mathrm{CDOM}}(443)$ relationship established in the present study were used to generate their normality of distribution by using $10^{5}$ of iteration for each of the variables (the int or the slo each is a vector having $10^{5}$ of data, hereafter referred to as int and slo; vector in bold). The number of data (i.e., $10^{5}$ ) was determined so as to obtain a standard error of the DOC estimate $<0.1 \%$ (in black; right axis of Fig. A1). Similarly, normality of distribution of $\mathrm{a}_{\mathrm{CDOM}}(443)$ was also generated using the mean of the measured value (obtained from Fig. 7) and the standard deviation was set to be $12 \%$ of the mean (the uncertainty of satellite retrievals of $\mathrm{a}_{\mathrm{CDOM}}(443)$; see Section 3.2 and Table 3 ; the $\mathbf{a}_{\text {CDOм }}(443)$ is also a vector having $10^{5}$ of data). The int, slo, and $\mathbf{a}_{\text {CDOM }}(443)$ values were then introduced into our DOC versus $\mathrm{a}_{\mathrm{CDOM}}(443)$ relationship to estimate DOC concentrations $\left(10^{5}\right.$ of DOC estimates). The coefficient of variation (CV) for the DOC estimates was calculated to be $28 \%$ (in red; left axis of Fig. A1) and determined as the uncertainty in the present study.

\section{References}

Aas, E., Hokedal, J., Hojerslev, N.H., Sandvik, R., Sakshaug, E., 2002. Spectral properties and UV-attenuation in Arctic marine waters. In: Hessen, D.O. (Ed.), UV Radiation and Arctic Ecosystems. Springer, Berlin.

Alling, V., Sanchez-Garcia, L., Porcelli, D., Pugach, S., Vonk, J.E., van Dongen, B., Morh, C.-M., Anderson, L.G., Sokolov, A., Andersson, P., Humborg, C., Semiletov, I., Gustafsson, O., 2010. Nonconservative behavior of dissolved organic carbon across the Laptev and east Siberian seas, Global Biogeochem. Cycle 24, GB4033. http://dx. doi.org/10.1029/2010GB003834.

Amon, R., 2004. The role of dissolved organic matter for the organic carbon cycle in the Arctic Ocean. In: Stein, R., Macdonald, R.W. (Eds.), The Organic Carbon Cycle in the Arctic Ocean. New York, Springer.

Amon, R.M.W., Rinehart, A.J., Duan, S., Louchouarn, P., Prokushkin, A., Guggenberger, G., Bauch, D., Stedmon, C., Raymond, P.A., Holmes, R.M., McClelland, J.W., Peterson, B.J., Walker, S.A., Zhulidov, A.V., 2012. Dissolved organic matter sources in large Arctic rivers. Geochim. Cosmochim. Acta 94, 217-237.
Antoine, D., Hooker, S.B., Belanger, S., Matsuoka, A., Babin, M., 2013. Apparent optical properties of the Canadian Beaufort Sea - part 1: observational overview and water column relationships. Biogeosciences 10, 4493-4509. http://dx.doi.org/10.5194/bg10-4493-2013.

Asmala, E., Bowers, D.G., Autio, R., Kaartokallio, H., Thomas, D.N., 2014. Qualitative changes of riverine dissolved organic matter at low salinities due to flocculation. J. Geophys. Res. 119. http://dx.doi.org/10.1002/2014JG002722.

Babin, M., Stramski, D., Ferrari, G.M., Claustre, H., Bricaud, A., Obolensky, G., Hoepffner, N., 2003. Variations in the light absorption coefficients of phytoplankton, nonalgal particles, and dissolved organic matter in coastal waters around Europe. J. Geophys. Res. 108. http://dx.doi.org/10.1029/2001JC00082.

Bailey, S., Werdell, P.J., 2006. A multi-sensor approach for the on-orbit validation of ocean color satellite data products. Remote Sens. Environ. 102, 12-23.

Bélanger, S., Xie, H., Krotkov, N., Larouche, P., Vincent, W.F., Babin, M., 2006. Photomineralization of terrigenous dissolved organic matter in Arctic coastal waters from 1979 to 2003: interannual variability and implications of climate change. Glob. Biogeochem. Cycles 20. http://dx.doi.org/10.1029/2006GB002708.

Boss, E., Gildor, H., Slade, W., Sokoletsky, L., Oren, A., Loftin, J., 2013. Optical properties 
of the Dead Sea. J. Geophys. Res. 118, 1821-1829. http://dx.doi.org/10.1002/jgrc 20109.

Bricaud, A., Babin, M., Claustre, H., Ras, J., Tièche, F., 2010. Light absorption properties and absorption budget of Southeast Pacific waters. J. Geophys. Res. 115, C0800. http://dx.doi.org/10.1029/2009JC005517.

Carlson, C.A., Hansell, D.A., Nelson, N.B., Siegel, D.A., Smethie, W.M., Khatiwala, S., Meyers, M.M., Halewood, E., 2010. Dissolved organic carbon export and subsequent remineralization in the mesopelagic and bathypelagic realms of the North Atlantic basin. Deep-Sea Res., Part II 57, 1433-1445.

Chekalyuk, A., Hafez, M., 2008. Advanced laser fluorometry of natural aquatic environments. Limnol. Oceanogr. Methods 6, 591-609.

Chekalyuk, A., Hafez, M., 2013. Analysis of spectral excitation for measurements of fluorescence constituents in natural waters. Opt. Express 21 (24). http://dx.doi.org/ 10.1364/OE.21.029255.

Chekalyuk, A., Barnard, A., Quigg, A., Hafez, M., Zhao, Y., 2014. Aquatic laser fluorescence analyzer: field evaluation in the northern Gulf of Mexico. Opt. Express 22 (18). http://dx.doi.org/10.1364/OE.22.021641.

Chekalyuk, A., Hafez, M., Tara Oceans Consortium, Coordinators, Tara Oceans Expedition, Participants, 2016. Properties of Seawater and Particulate Matter from a WETLabs ALFA Hyperspectral Laser Spectrofluorometer Mounted on the Continuous Surface Water Sampling System During the Tara Oceans Expedition 2009-2013. http://dx.doi.org/10.1594/PANGAEA.861926.

Comeau, A.M., Li, W.K.W., Tremblay, J.-E., Carmack, E.C., Lovejoy, C., 2011. Arctic Ocean microbial community structure before and after the 2007 record sea ice minimum. PLoS One 6 (11), 1-12.

Doxaran, D., Devred, E., Babin, M., 2015. A 50\% increase in the mass of terrestrial particles delivered by the Mackenzie River into the Beaufort Sea (Canadian Arctic Ocean) over the last 10 years. Biogeosciences 12, 3551-3565. http://dx.doi.org/10 5194/bg-12-3551-2015.

Floge, S.A., Hardy, K.R., Boss, E., Wells, M.L., 2009. Analytical intercomparison between type I and type II long-pathlength liquid core waveguides for the measurement of chromophoric dissolved organic matter. Limnol. Oceanogr. Methods 7, 260-268.

Goncalves-Araujo, R., Stedmon, C.A., Heim, B., Dubinenkov, I., Kraberg, A., Moiseev, D., Brancher, A., 2015. From fresh to marine waters: characterization and fate of dissolved organic matter in the Lena River delta region, Siberia. Front. Mar. Sci. 2. http://dx.doi.org/10.3389/fmars.2015.00108.

Gordon, H.R., 1999. Contribution of Raman scattering to water-leaving radiance: a reexamination. Appl. Opt. 38 (15), 3166-3174.

Guéguen, C.F., McLaughlin, A., Carmack, E.C., Itoh, M., Narita, H., Nishino, S., 2012. The nature of colored dissolved organic matter in the southern Canada Basin and East Siberian Sea. Deep-Sea Res. II 81-84, 102-113.

Hansell, D., 2002. DOC in the global ocean carbon cycle. In: Hansell, D.A., Craig, C.A (Eds.), Biogeochemistry of Marine Dissolved Organic Matter. Academic press, California.

Heim, B., Abramova, E., Doerffer, R., Günther, F., Hölemann, J., Kraberg, A., Lantuit, H., Loginova, A., Martynov, F., Overduin, P. P., Wegner, C. 2014. Ocean colour remote sensing in the southern Laptev Sea: evaluation and applications. Biogeosciences 11, $4191-4210$.

Hessen, D.O., Carroll, J., Kjeldstad, B., Korosov, A.A., Pettersson, L.H., Pozdnyakov, D., Sørensen, K., 2010. Input of organic carbon as determinant of nutrient fluxes, light climate and productivity in the $\mathrm{Ob}$ and Yenisey estuaries. Estuar. Coast. Shelf Sci. 88, $53-62$.

Holmes, R.M., McClelland, J.W., Peterson, B.J., Shiklomanov, I.A., Shiklomanov, A.I., Zhulidov, A.V., Gordeev, V.V., Bobrovitskaya, N.N., 2002. A circumpolar perspective on fluvial sediment flux to the Arctic Ocean. Glob. Biogeochem. Cycles 16 (4). http:// dx.doi.org/10.1029/2001GB001849.

Holmes, R.M., McClelland, J.W., Peterson, B.J., Tank, S.E., Bulygina, E., Eglinton, T.I., Gordeev, V.V., Gurtovaya, T.Y., Raymond, P.A., Repeta, D.J., Staples, R., Striegl, R.G., Zhulidov, A.V., Zimov, S.A., 2012. Seasonal and annual fluxes of nutrients and organic matter from large rivers to the Arctic Ocean and surrounding Seas. Estuar. Coasts 35, 369-382

Hooker, S.B., Morrow, J.H., Matsuoka, A., 2013. The $1 \%$ and $1 \mathrm{~cm}$ perspective in validating and deriving AOP data products. Biogeosciences 10, 4511-4527. http://dx doi.org/10.5194/bg-10-4511-2013.

IOCCG, 2015. Ocean colour remote sensing in polar seas. In: Babin, M., Arrigo, K.R., Belanger, S., Forget, M.-H. (Eds.), IOCCG Report Series, No. 16. Darmouth, Canada.

IPCC, 2007. In: Solomon, S., Qin, D., Manning, M., Chen, Z., Marquis, M., Averyt, K.B., Tignor, M., Miller, H.L. (Eds.), Climate Change 2007: the Physical Science Basis. Contribution of Working Group I to the Fourth Assessment Report of the Intergovernmental Panel on Climate Change. Cambridge University Press, Cambridge, United Kingdom and New York, NY, USA.

IPCC, 2013. In: Stocker, T.F., Qin, D., Plattner, G.-K., Tignor, M., Allen, S.K., Boschung, J., Nauels, A., Xia, Y., Bex, V., Midgley, P.M. (Eds.), Climate Change 2013: the Physical Science Basis. Contribution of Working Group I to the Fifth Assessment Report of the Intergovernmental Panel on Climate Change. Cambridge University Press, Cambridge, United Kingdom and New York, NY, USA 1535 pp. http://dx.doi.org/10. $1017 / \mathrm{CBO} 9781107415324$

Jerlov, N.G., 1976. Marine Optics. Elsevier scientific publishing company, Amsterdam.

Kirk, J.T.O., 1994. Light and Photosynthesis in Aquatic Ecosystems, 2nd ed. Cambridge Univ. Press, New York.

Le Fouest, V., Zakardjian, B., Xie, H., Raimbault, P., Joux, F., Babin, M., 2013. Modeling plankton ecosystem functioning and nitrogen fluxes in the oligotrophic waters of the Beaufort Sea, Arctic Ocean: a focus on light-driven processes. Biogeosciences 10, 4785-4800. http://dx.doi.org/10.5194/bg-10-4785-2013.

Lee, Z., Hu, C., Shang, S., Du, K., Lewis, M., Arnone, R., Brewin, R., 2013. Penetration of UV-visible solar radiation in the global oceans: insights from ocean color remote sensing. J. Geophys. Res. 118, 1-15. http://dx.doi.org/10.1002/jgrc.20308.

Legendre, P., Legendre, L., 1998. Numerical Ecology. York, New.

Li, W.K.W., MaLaughlin, F.A., Lovejoy, C., Carmack, E.C., 2009. Smallest algae thrive as the Arctic Ocean freshens. Science 326, 539.

Loisel, H., Morel, A., 2001. Non-isotropy of the upward radiance field in typical coastal (case 2) waters. Int. J. Remote Sens. 22 (2), 275-295.

Manizza, M., Follows, M.J., Dutkiewicz, S., McClelland, J.W., Menemenlis, D., Hill, C.N., Townsend-Small, A., Peterson, B.J., 2009. Modeling transport and fate of riverine dissolved organic carbon in the Arctic Ocean. Global Biogeochem. Cyc. 23, GB4006. http://dx.doi.org/10.1029/2008GB003396.

Mann, P.J., Eglinton, T.I., McIntyre, C.P., Zimov, N., Davydova, A., Vonk, J.E., Holmes, R.M., Spencer, R.G.M., 2015. Utilization of ancient permafrost carbon in headwaters of Arctic fluvial networks. Nature Comm. 6, 7856. http://dx.doi.org/10.1038/ ncomms8856.

Mannino, A., Russ, M.E., Hooker, S.B., 2008. Algorithm development and validation for satellite-derived distributions of DOC and CDOM in the U.S. Middle Atlantic Bight. J. Geophys. Res. 113, C07051. http://dx.doi.org/10.1029/2007JC004493.

Massicotte, P., Asmala, E., Markager, S., Stedmon, C.A., 2017. Global patterns in the relationship of DOC and spectral CDOM absorbance: from lakes to oceans. Sci. Total Environ (in press).

Matsuoka, A., Hill, V., Huot, Y., Bricaud, A., Babin, M., 2011. Seasonal variability in the light absorption properties of western Arctic waters: parameterization of the in dividual components of absorption for ocean color applications. J. Geophys. Res. 116 http://dx.doi.org/10.1029/2009JC005594.

Matsuoka, A., Bricaud, A., Benner, R., Para, J., Sempéré, R., Prieur, L., Bélanger, S., Babin, M., 2012. Tracing the transport of colored dissolved organic matter in water masses of the Southern Beaufort Sea: relationship with hydrographic characteristics. Biogeosciences 9, 2012. http://dx.doi.org/10.5194/bg-9-925-2012.

Matsuoka, A., Hooker, S.B., Bricaud, A., Gentili, B., Babin, M., 2013. Estimating absorption coefficients of colored dissolved organic matter (CDOM) using a semi-analytical algorithm for southern Beaufort Sea waters: applications to deriving concentrations of dissolved organic carbon from space. Biogensci. 10. http://dx.doi.org/ 10.5194/bg-10-917-2013.

Matsuoka, A., Babin, M., Doxaran, D., Hooker, S.B., Mitchell, B.G., Bélanger, S., Bricaud, A., 2014. A synthesis of light absorption properties of the Arctic Ocean: application to semianalytical estimates of dissolved organic carbon concentrations from space. Biogeosciences 11, 3131-3147. http://dx.doi.org/10.5194/bg-11-3131-2014.

Matsuoka, A., Ortega-Retuerta, E., Bricaud, A., Arrigo, K.R., Babin, M., 2015. Characteristics of colored dissolved organic matter (CDOM) in the Western Arctic Ocean: relationships with microbial activities. Deep-Sea Res. II Top. Stud. Oceanogr. 118, 44-52.

Matsuoka, A., Babin, M., Devred, E.C., 2016. A new algorithm for discriminating water sources from space: a case study for the southern Beaufort Sea using MODIS ocean color and SMOS salinity data. Remote Sens. Environ. 184, 124-138.

McGuire, A.D., Anderson, L.G., Christensen, T.R., Dallimore, S., Guo, L., Hayes, D.J., Heimann, M., Lorenson, T.D., Macdonald, R.W., Roulet, N., 2009. Sensitivity of the carbon cycle in the Arctic to climate change. Ecol. Monogr. 79 (4), 523-555.

Miller, W.L., Moran, M.A., Sheldon, W.M., Zepp, R.G., Opsahl, S., 2002. Determination of apparent quantum yield spectra for the formation of biologically labile photoproducts. Limnol. Oceanogr. 47, 343-352.

Monahan, E.C., Pybus, M.J., 1978. Colour, ultraviolet absorbance and salinity of the surface waters off the west coast of Ireland. Nature 274, 782-784.

Moran, M.A., Zepp, R.G., 1997. Role of photoreactions in the formation of biologically labile compounds from dissolved organic matter. Limnol. Oceanogr. 42 (6), 1307-1316.

Morel, A., Gentili, B., 1991. Diffuse reflectance of oceanic waters: its dependence on Sun angles as influenced by the molecular scattering contribution. Appl. Opt. 30 (30), $4427-4438$.

Morel, A., Gentili, B., 1993. Diffuse reflectance of oceanic waters. II. Bidirectional aspects. Appl. Opt. 32 (33), 6864-6879.

Morel, A., Prieur, L., 1977. Analysis of variations in ocean color. Limnol. Oceanogr. 22 (4), 709-722.

Morrow, J.H., Hooker, S.B., Booth, C.R., Bernhard, G., Lind, R.N., Brown, J.W., 2010 Advances in Measuring the Apparent Optical Properties (AOPs) of Optically Complex Waters, NASA Tech. Memo., 2010-215856. NASA Goddard Space Flight Center, Greenbelt, Maryland, pp. 42-50.

Mueller, J.L., Austin, R.W., 1995. In: Hooker, S.B., Firestone, E.R., Acker, J.G. (Eds.) Ocean Optics Protocols for SeaWiFS Validation, Revision 1. NASA Tech. Memo. 104566. Vol. 25 NASA GSFC, Greenbelt, Maryland 67 pp.

Nelson, N.B., Siegel, D.A., 2002. Chromophoric DOM in the open ocean. In: Hansell, D.A., Carlson, C.A. (Eds.), Biogeochemistry of Marine Dissolved Organic Matter. Academic press, San Diego.

Nieke, B., Reuter, R., Heuermann, R., Wang, H., Babin, M., Therriault, J.C., 1997. Light absorption and fluorescence properties of chromophoric dissolved organic matter (CDOM), in the St. Lawrence Estuary (case 2 waters). Cont. Shelf Res. 17, 235-252.

Orek, H., Doerffer, R., Rottgers, R., Boersma, M., Wiltshire, K.H., 2013. A bio-optical model for remote sensing of Lena water. Biogeosci. Discuss. 10, 4888-4925.

Ortega-Retuerta, E., Jeffrey, W.H., Babin, M., Bélanger, S., Benner, R., Marie, D., Matsuoka, A., Raimbault, P., Joux, F., 2012. Carbon fluxes in the Canadian Arctic: patterns and drivers of bacterial abundance, production and respiration on the Beaufort Sea margin. Biogeosciences 9, 3679-3692.

Osburn, C.L., Retamal, L., Vincent, W.F., 2009. Photoreactivity of chromophoric dissolved organic matter transported by the Mackenzie River to the Beaufort Sea. Mar. Chem. $115,10-20$.

Osburn, C.L., Boyd, T.J., Montgomery, M.T., Bianchi, T.S., Coffin, R.B., Paerl, H.W., 2016 Optical proxies for terrestrial dissolved organic matter in estuaries and coastal 
waters. Front. Mar. Sci. 2. http://dx.doi.org/10.3389/fmars.2015.00127.

Para, J., Charrière, B., Matsuoka, A., Miller, W.L., Rontani, J.F., Sempéré, R., 2012. UV/ $\mathrm{PAR}$ radiations and DOM properties in surface coastal waters of the Canadian shelf of the Beaufort Sea during summer 2009. Biogeosciences 10. http://dx.doi.org/10. 5194/bg-10-2761-2013.

Pegau, W.S., Gray, D., Zaneveld, J.R., 1997. Absorption and attenuation of visible and near-infrared light in water: dependence on temperature and salinity. Appl. Opt. 36 (24), 6035-6046.

Raymond, P.A., McClelland, J.W., Holmes, R.M., Zhulidov, A.V., Mull, K., Peterson, B.J., Striegl, R.G., Aiken, G.R., Gurtovaya, T.Y., 2007. Flux and age of dissolved organic carbon exported to the Arctic Ocean: A carbon isotopic study of the five largest arctic rivers. Glob. Biogeochem. Cycles 21, GB4011. http://dx.doi.org/10.1029/ 2007 GB002934.

Retamal, L., Vincent, W.F., Martineau, C., Osburn, C.L., 2007. Comparison of the optical properties of dissolved organic matter in two river-influenced coastal regions of the Canadian Arctic. Estuar. Coast. Shelf Sci. 72, 261-272.

Retamal, L., Bonilla, S., Vincent, W.F., 2008. Optical gradients and phytoplankton production in the Mackenzie River and the coastal Beaufort Sea. Polar Biol. 31, 363-379.

Shen, Y., Fichot, C.G., Benner, R., 2012. Dissolved organic matter composition and bioavailability reflect ecosystem productivity in the Western Arctic Ocean.
Biogeosciences 9, 4993-5005. http://dx.doi.org/10.5194/bg-9-4993-2012.

Shen, Y., Benner, R., Robbins, L.L., Wynn, J.G., 2016. Sources, distributions and dynamics of dissolved organic matter in the Canada and Makarov Basins. Front. Mar. Sci. 3 (198). http://dx.doi.org/10.3389/fmars.2016.00198.

Spencer, R.G.M., Mann, P.J., Dittmar, T., Eglinton, T.I., McIntyre, C., Holmes, R.M., Zimov, N., Stubbins, A., 2015. Detecting the signature of permafrost thaw in Arctic rivers. Geophys. Res. Lett. 42, 2830-2835. http://dx.doi.org/10.1002/ 2015 GL063498.

Stedmon, C.A., Markager, S., 2005. Resolving the variability in dissolved organic matter fluorescence in a temperate estuary and its catchment using PARAFAC analysis. Limnol. Oceanogr. 50 (2), 686-697.

Stedmon, C.A., Amon, R.M.W., Rinehart, A.J., Walker, S.A., 2011. The supply and characteristics of colored dissolved organic matter (CDOM) in the Arctic Ocean: Pan Arctic trends and differences. Mar. Chem. 124, 108-118.

Twardowski, M.S., Sullivan, J.M., Donaghay, P.L., Zaneveld, J.R., 1999. Microscale quantification of the absorption by dissolved and particulate material in coastal waters with an ac-9. J. Atmos. Ocean. Technol. 16, 691-707.

Walker, S.A., Amon, R.M.W., Stedmon, C.A., 2013. Variations in high-latitude riverine fluorescent dissolved organic matter: A comparison of large Arctic rivers. J. Geophys. Res. 118, 1-14. http://dx.doi.org/10.1002/2013/JG002320. 